\title{
金属催化剂催化醇和胺直接偶联制备亚胺的研究进展
}

\author{
王辉黄龙江* \\ (青岛科技大学化工学院 青岛 266042)
}

\begin{abstract}
摘要 亚胺又称席夫碱, 广泛存在于天然产物、生物活性化合物和药物等分子结构中. 亚胺中的 $\mathrm{C}=\mathrm{N}$ 双键具有较高的 反应活性，可作为氮源应用于不同类型的反应中，因此在生物、医药、染料和材料等方面都有重要应用. 金属催化剂催 化醇胺直接偶联制备亚胺因具有原子经济性高、绿色环保等优点, 近年来获得了广泛关注并取得了重要进展. 系统地 总结和评述了近年来金属催化剂催化醇和胺直接偶联制备亚胺反应的研究进展, 并对其未来发展方向进行了展望.

关键词 亚胺; 醇; 胺; 金属催化
\end{abstract}

\section{Progress in Imine Formation from Direct Coupling of Alcohols and Amines Catalyzed by Metal Catalysts}

\author{
Wang, Hui Huang, Longjiang* \\ (College of Chemical Engineering, Qingdao University of Science and Technology, Qingdao 266042)
}

\begin{abstract}
Imines are very important class of compounds and have been widely utilized in fine chemicals, pharmaceuticals and chemical industry. The $\mathrm{C}=\mathrm{N}$ double bond in imine is an important nitrogen source in different types of reactions due to its high reactive activity. Due to its high atom economy, catalytic direct coupling of alcohols and amines to imines based on metal catalysts has attracted much attention and maken great progress in recent years. In this paper, the advances in direct coupling of alcohols and amines to imines catalyzed by metal catalysts are reviewed.

Keywords imine; alocohols; amines; metal catalysis
\end{abstract}

亚胺又称席夫碱，是指醛或酮上氧原子被氮原子取 代而形成的一类含碳氮双键的有机化合物, 广泛存在于 天然产物、生物活性化合物和药物结构中 ${ }^{[17]} ;$ 同时, 该 结构具有较高的反应活性, 可作为氮源应用于不同类型 的反应中, 因此在染料、香料、杀菌剂、药品和农用化 学品等方面都具有重要的应用 ${ }^{[8 ~ 18]}$. 传统的亚胺制备方 法包括酸催化下羰基与伯胺的缩合 ${ }^{[19]}$ 、次胺的氧化 ${ }^{[20,21]}$ 等, 其中, 酸催化下羰基与胺的反应是最常用的亚胺制 备方法. 相比于酫和酮, 醇类化合物在多数情况下是更 稳定和易得的原料; 催化醇和胺直接偶联制备亚胺唯一 的副产物为水, 因此具有原子经济性高和环境友好等优 点. 近年来催化醇胺偶联制备亚胺的方法引起了广泛关 注, 并在催化剂尤其是金属催化剂的开发方面取得了一 定的进展, 本文系统地总结了金属催化剂催化醇和胺直
接偶联制备亚胺的研究进展, 并依据反应机理不同将其 分为催化氧化和催化脱氢两大类.

\section{1 醇与胺的催化氧化缩合}

\section{1 钯类催化剂}

2009 年, Park 等 ${ }^{[22]}$ 将钯金属纳米颗粒包埋在勃姆石 纳米纤维中, 制备了一种非均相钯催化剂 $\mathrm{Pd} / \mathrm{AlO}(\mathrm{OH})$, 并将其用于催化醇和胺偶联制备亚胺的反应. 在 2.0 $\mathrm{mol} \%$ 催化剂和氧气存在下, 芐醇和苯乙胺在正庚烷中 于 $90{ }^{\circ} \mathrm{C}$ 反应 $20 \mathrm{~h}$, 亚胺的收率达到 $90 \%$ (Scheme 1). 底 物拓展发现芐醇类底物中芳环上取代基的电子效应(如 4-甲氧基、4-氟)不影响亚胺收率; 苯胺类底物与茮醇的 反应则需更多的催化剂(4 mol\%)才能获得满意的收率;

\footnotetext{
* Corresponding author. E-mail: huanglj@qust.edu.cn Received August 30, 2018; revised November 14, 2018; published online December 5, 2018. Project supported by the Higher Educational Science and Technology Program of Shandong Province (No. J16LC13). 山东省高等教育科技计划(No. J16LC13)资助项目.
} 


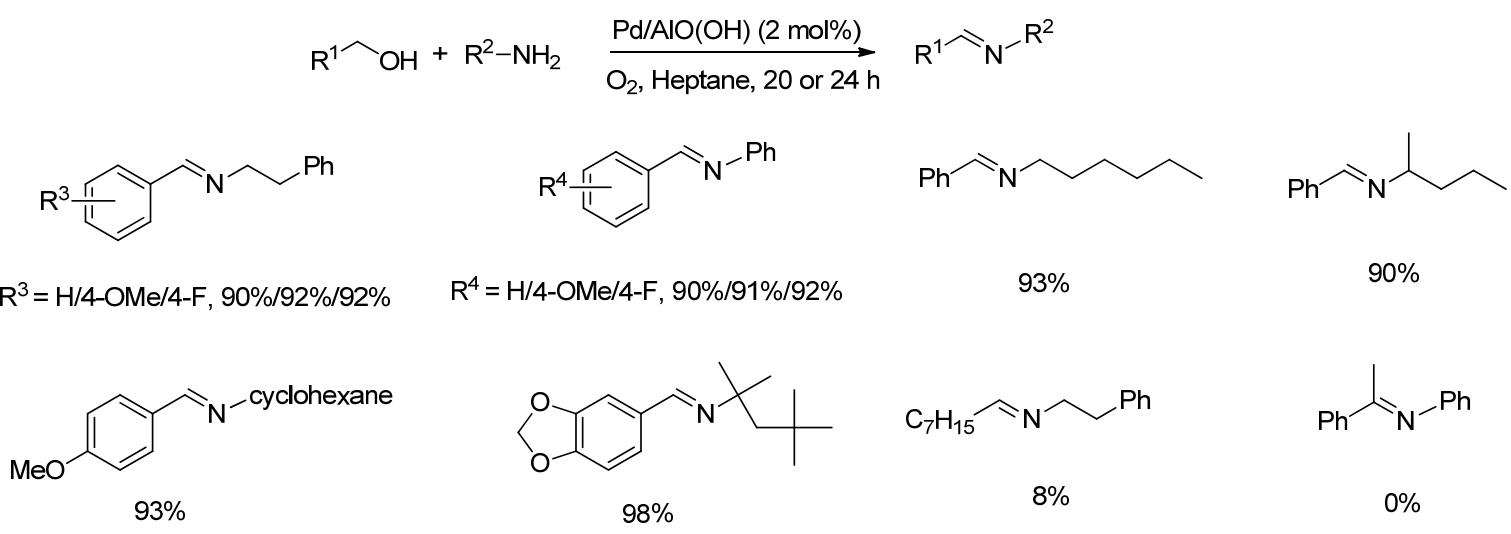

图式 $1 \mathrm{Pd} / \mathrm{AlO}(\mathrm{OH})$ 催化剂催化醇和胺直接偶联生成亚胺的反应

Scheme 1 Direct coupling of alcohols and amines catalyzed by $\mathrm{Pd} / \mathrm{AlO}(\mathrm{OH})$

脂肪胺分子中烷基的空间体积不影响目标产物的收率, 如 2,4,4-三甲基戊烷-2-胺与茮醇反应的收率为 98\%; 正 辛醇与苯乙胺的反应收率只有 $8 \%, 1$-苯乙醇与苯胺反应 则未得到目标产物. 在催化醇和胺偶联的过程中除氧气 外不需要其它任何添加剂, 有一定的底物适用范围, 是 一种相对绿色且较有效的亚胺制备方法.

2011 年, $X u$ 等 ${ }^{[23]}$ 研究了钯催化下苄醇和茮胺的直 接偶联反应, 在 $1 \mathrm{~mol} \%$ 醋酸钯 $\left(\mathrm{Pd}(\mathrm{OAc})_{2}\right) 、 15 \mathrm{~mol} \%$ 三 乙胺、 $4 \mathrm{~mol} \%$ 四甲基哌啶氧化物(TEMPO)、 $20 \mathrm{~mol} \%$ $t$ - $\mathrm{BuOK}$ 和空气存在的条件下, 茮醇和茮胺室温反应 $3 \mathrm{~d}$, 亚胺收率达 $99 \%$. 对于苦醇和脂肪胺类底物, 能以 76\% 99\%的收率得到目标产物; 对于苦醇和取代苯胺 类底物，可采用增加叔丁醇钾用量来提高收率 $(50 \mathrm{~mol} \%$
或 $100 \mathrm{~mol} \%$ ). 机理研究表明，该反应先经历了醇在钯 催化下氧化为醛, 随后醛和胺反应生成亚胺的过程, 但 催化过程中金属钯以何种活性态存在尚不明确. 该方法 不需要溶剂且反应条件非常温和，底物适用范围广，但 反应时间偏长且反应体系需要多种添加物, 对于碱性较 弱的苯胺类底物, 收率偏低.

2017 年, Dong 等 ${ }^{[24]}$ 以 4,4,4-三氟-1-(4-(吡啶-4-基) 苯基)丁烷-1,3-二酮和 $\mathrm{Mn}(\mathrm{OAc})_{2}$ 为原料, 在溶液中合成 了新的 $\mathrm{Mn}(\mathrm{II})$ 金属有机骨架 $(\mathrm{MOF})$, 并将该 $\mathrm{MOF}$ 作为 $\mathrm{Pd}-\mathrm{Au}$ 双金属合金纳米粒子的载体，得到了一种高活性 含双官能团非均相复合催化体系 Pd-Au@Mn(II)-MOF. 该催化体系在空气条件下，能有效地促进醇和胺 “一锅

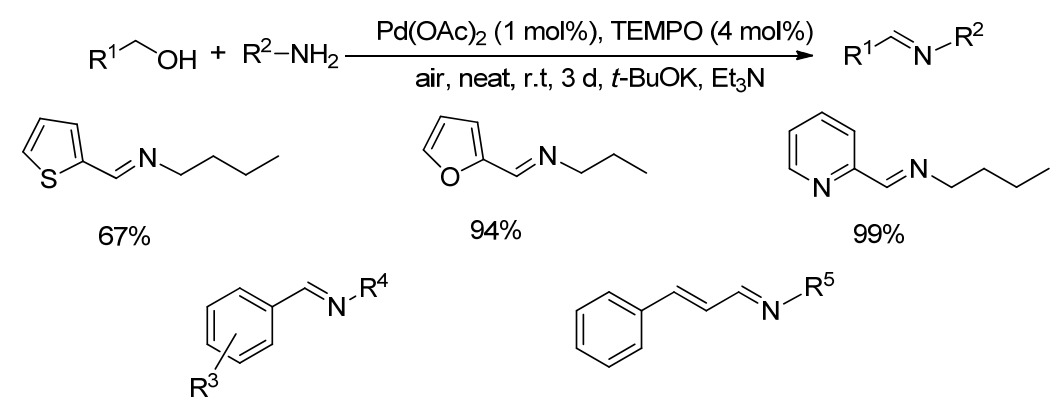

$$
\begin{array}{ll}
\mathrm{R}_{3}=\mathrm{H}, \mathrm{R}^{4}=n-\mathrm{C}_{4} \mathrm{H}_{9}, 99 \% & \mathrm{R}^{3}=4-\mathrm{MeO}, \mathrm{R}^{4}=\mathrm{Bn}, 98 \% \\
\mathrm{R}^{3}=\mathrm{H}, \mathrm{R}^{4}=\mathrm{Ph}, 75 \% & \mathrm{R}^{3}=4-\mathrm{MeO}, \mathrm{R}^{4}=n-\mathrm{C}_{4} \mathrm{H}_{9}, 99 \% \\
\mathrm{R}^{3}=\mathrm{H}, \mathrm{R}^{4}=n-\mathrm{C}_{8} \mathrm{H}_{17}, 99 \% & \mathrm{R}^{3}=4-\mathrm{MeO}, \mathrm{R}^{4}=n-\mathrm{C}_{8} \mathrm{H}_{17}, 98 \% \\
\mathrm{R}^{3}=\mathrm{H}, \mathrm{R}^{4}=4-\mathrm{MeC}_{6} \mathrm{H}_{4}, 41 \% & \mathrm{R}^{3}=4-\mathrm{MeO}, \mathrm{R}^{4}=\mathrm{Ph}, 67 \% \\
\mathrm{R}^{3}=\mathrm{H}, \mathrm{R}^{4}=4-\mathrm{ClC}_{6} \mathrm{H}_{4}, 35 \% & \mathrm{R}^{3}=\mathrm{H}, \mathrm{R}^{4}=2-\mathrm{MeOC}_{6} \mathrm{H}_{4}, 36 \% \\
\mathrm{R}^{3}=\mathrm{H}, \mathrm{R}^{4}=2-\mathrm{MeC}_{6} \mathrm{H}_{4},(43 \%) & \mathrm{R}^{3}=4-\mathrm{OMe}, \mathrm{R}^{4}=4-\mathrm{ClC}_{6} \mathrm{H}_{4}, 43 \% \\
\mathrm{R}^{3}=\mathrm{H}, \mathrm{R}^{4}=2-\mathrm{ClC}_{6} \mathrm{H}_{4},(21 \%) & \mathrm{R}^{3}=4-\mathrm{NO}_{2}, \mathrm{R}^{4}=n-\mathrm{C}_{4} \mathrm{H}_{9}, 99 \% \\
\mathrm{R}^{3}=4-\mathrm{Cl}, \mathrm{R}^{4}={ }_{n}-\mathrm{C}_{4} \mathrm{H}_{9}, 99 \% & \mathrm{R}^{3}=4-\mathrm{OMe}^{4}, \mathrm{R}^{4}=\mathrm{Ph}, 67 \% \\
\mathrm{R}^{3}=4-\mathrm{OMe}, \mathrm{R}^{4}=2-\text { furanmethyl, } 91 \% & \mathrm{R}^{5}=n-\mathrm{C}_{4} \mathrm{H}_{9}, 97 \% \\
\mathrm{R}^{3}=4-\mathrm{Me}, \mathrm{R}^{4}=\mathrm{Bn}, 76 \% & \mathrm{R}^{5}=n-\mathrm{C}_{8} \mathrm{H}_{17}, 70 \% \\
& \mathrm{R}^{5}=\mathrm{Ph}, 46 \%
\end{array}
$$

图式 2 醋酸钯催化醇和胺直接偶联生成亚胺的反应

Scheme 2 Direct coupling of alcohols and amines catalyzed by $\mathrm{Pd}(\mathrm{OAc})_{2}$ 
法” 串联反应合成亚胺(Scheme 3). 对于 19 种茮醇和茮 胺类底物, 该方法以 $0.75 \mathrm{~mol} \% \mathrm{Pd}-\mathrm{Au}$ 为催化剂, 在甲 苯中 $110{ }^{\circ} \mathrm{C}$ 反应 $24 \mathrm{~h}$, 收率在 49\% 99\%之间. 当芐胺 芳环对位为强的供电性基团(如甲氧基)取代时，目标产 物收率普遍较低. 而对于 27 种茮醇和苯胺类底物, 则需 要在反应体系中添加 $10 \mathrm{~mol} \%$ 的氢氧化钠, 收率在 49\% 99\%之间，两种底物芳环上取代基的类型和位置 对产物收率都有较大影响.

\section{2 铜类催化剂}

2012 年, $\mathrm{Xu}$ 等 ${ }^{[25]}$ 以茮醇和茮胺为模型底物, 研究了 铜催化剂催化醇和胺直接合成亚胺的方法(Scheme 4). 在空气存在下, 以 $1 \mathrm{~mol} \%$ 的碘化亚铜为催化剂, $1 \mathrm{~mol} \%$ 的 2,2'-联吡啶为配体，茮醇和茮胺在 $2 \mathrm{~mol} \%$ 的 TEMPO 存在下乙腈中室温反应 $6 \mathrm{~h}$, 以 $99 \%$ 的收率得到目标亚 胺产物. 该方法底物范围较广, 适合苄醇、烯丙醇、炔 丙醇、脂肪醇类底物和脂肪胺、芳香胺类底物, 收率在
64\% 99\%之间，并可以放大到 $100 \mathrm{mmol}$ 的规模. 手性 胺类底物在反应过程中不发生消旋。在整个反应过程 中，碘化亚铜不仅具有促进醇氧化的作用，同时还能提 高醛和胺的脱水反应速率. 该催化方法不需要添加碱和 脱水剂，催化剂廉价易得，条件温和，底物适用范围广， 是一种有效的亚胺制备方法.

同年, Zhang 等 ${ }^{[26]}$ 研究了 $\mathrm{Cu}\left(\mathrm{ClO}_{4}\right)_{2} \bullet 6 \mathrm{H}_{2} \mathrm{O}$ 催化下醇 和胺的亚胺化反应. 该方法以 $5 \mathrm{~mol} \%$ 的 $\mathrm{Cu}\left(\mathrm{ClO}_{4}\right)_{2} \bullet$ $6 \mathrm{H}_{2} \mathrm{O}$ 为催化剂、 1.5 equiv. 氢氧化钾为碱, 氧气存在下甲 苯中于 $70{ }^{\circ} \mathrm{C}$ 反应 $22 \mathrm{~h}$ (Scheme 5). 除大位阻的 2,4,6-三 甲基苯胺外, 茮醇与芳胺、茮胺、脂肪胺类底物反应能 以 $63 \% \sim 97 \%$ 的收率得到目标产物，而正丁醇、十二醇 以及 1 -苯基-2-丙醇与各种胺的反应效果较差，均只能 得到痕量产物. 该方法催化剂较廉价, 但是反应过程需 要添加过量的碱.<smiles>NCc1cc[R]([CH+]OCc2ccc(CN)cc2)cc1</smiles>

$\underset{0.75 \mathrm{~mol} \% \mathrm{Pd}-\mathrm{Au} \text {, toluene }}{\longrightarrow}$ air, $24 \mathrm{~h}, 100^{\circ} \mathrm{C}$<smiles>[R]C1=CC=CC(C=NCc2ccccc2)=CC1[R]</smiles>

$48 \% \sim 99 \%$<smiles>[CH+]OCc1ccc(N)cc1</smiles><smiles>[R]c1ccc(N=Cc2ccc([R]3=Cc4ccccc43)cc2)cc1</smiles>

图式 3 含双官能团的非均相复合催化体系 $\mathrm{Pd}-\mathrm{Au} @ \mathrm{Mn}(\mathrm{II})-\mathrm{MOF}$ 催化醇和胺一锅合成亚胺的反应 Scheme 3 Direct coupling of alcohols and amines catalyzed by Pd-Au@Mn(II)-MOF

$$
\mathrm{R}^{1} \widehat{\mathrm{OH}}+\mathrm{R}^{2}-\mathrm{NH}_{2} \underset{2 \mathrm{~mol} \% \mathrm{TEMPO}, \mathrm{CH}_{3} \mathrm{CN} \text {, air, r.t. }}{\stackrel{\text { Cul (1 mol\%), Bipy (1 mol\%) }}{\longrightarrow}} \mathrm{R}^{1} \widehat{-}^{-}-\mathrm{R}^{2}
$$<smiles>CCCCN=Cc1ccccn1</smiles><smiles>[R19]CC(=O)OCc1ccccc1</smiles><smiles>O=C(OCCC=Nc1ccccc1)Oc1ccccc1</smiles><smiles>O=[Se]/C=C/c1cccs1</smiles><smiles>C(=N/c1ccccc1)\c1ccccc1</smiles>

$66 \% \sim 91 \%$

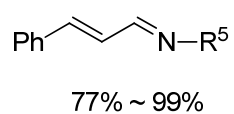$$
77 \% \sim 99 \%
$$

图式 4 铜催化剂催化醇和胺直接合成亚胺的反应

Scheme 4 Direct coupling of alcohols and amines catalyzed by copper catalysts

$$
\mathrm{R}^{1} \widehat{\mathrm{OH}}+\mathrm{R}^{2-\mathrm{NH}_{2}} \underset{\text { Toluene, } \mathrm{KOH}, 22 \mathrm{~h}, \mathrm{O}_{2}, 70^{\circ} \mathrm{C}\left(\mathrm{ClO}_{4}\right)_{2} \cdot 6 \mathrm{H}_{2} \mathrm{O}(5 \mathrm{~mol} \%)}{\longrightarrow} \mathrm{R}^{1} \mathrm{~N}^{-} \mathrm{R}^{2}
$$

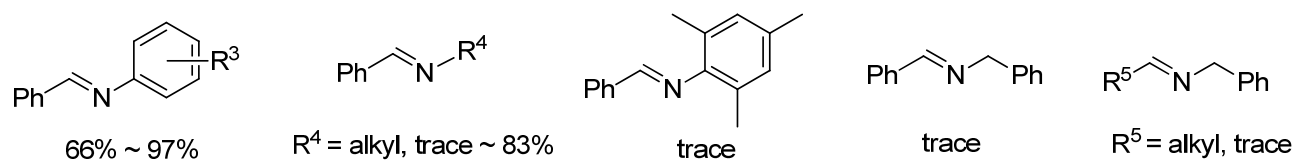

图式 5 碱性条件下 $\mathrm{Cu}\left(\mathrm{ClO}_{4}\right)_{2} \bullet 6 \mathrm{H}_{2} \mathrm{O}$ 催化醇和胺合成亚胺的反应

Scheme 5 Direct coupling of alcohols and amines catalyzed by $\mathrm{Cu}\left(\mathrm{ClO}_{4}\right)_{2} \bullet 6 \mathrm{H}_{2} \mathrm{O}$ 
2015 年, Bai 等 ${ }^{[27]}$ 以自制的荔枝型氧化亚铜 $\left(\mathrm{Cu}_{2} \mathrm{O}\right)$ 纳米团聚体替代 $\mathrm{Cu}\left(\mathrm{ClO}_{4}\right)_{2} \cdot 6 \mathrm{H}_{2} \mathrm{O}$ 作催化剂. 该催化方法 对芳环对位有供电子基团的芳胺类(如甲氧基、甲基苯 胺) 以及长链脂肪胺的催化效果较好, 收率达到 $84 \%$ 96\% (Scheme 6). 对于邻位有取代基的苯胺类底物(如 2甲氧基苯胺和 2-澳苯胺)与芐醇的反应, 亚胺收率仅为 50\%和 54\%, 对于 3-吡啶基甲醇与苄胺的反应, 亚胺收 率只有 $24 \%$. 该催化体系底物适用范围较窄, 反应体系 中需要加入过量的碱; 在反应过程中氧化亚铜可被氧化 为氧化铜, 整个过程起催化作用的是氧化亚铜还是氧化 铜, 尚不明确.

2017 年, Galia 等 ${ }^{[28]}$ 将配体与四甲基哌啶氮氧化物 结合制备了一类含配体的新型四甲基吡啶氮氧化物的 衍生物 BT, 并将其替代 TEMPO 与碘化亚铜组成催化 剂. 以芐醇和芐胺类化合物为反应底物, 当催化剂(碘 化亚铜和 BT) 的用量为底物的 $0.1 \mathrm{~mol} \%$ 时, 该催化剂的 转化数(TON)较高, 大都达到了 900 (Scheme 7). 对于苄 醇和脂肪胺或芳胺以及脂肪醇和茮胺类底物, 当催化剂 的用量为底物的 $0.1 \mathrm{~mol} \%$ 时, 目标产物的收率一般都 $<$ $10 \%$; 当将催化剂用量提升到底物的 $0.2 \mathrm{~mol} \%$, 同时延 长反应时间至 $24 \mathrm{~h}$, 目标亚胺的收率为 59\% 99\%. 该 方法催化剂用量少, 反应条件温和, 底物适用范围较广, 但 BT 不易制备. 其催化氧化机理如 Scheme 8 所示.
在上述有关铜类催化剂的研究中发现, 通常需要在 反应体系中添加碱、TEMPO 或有机配体等来提高收率, 但是这些添加物回收困难. 针对这一问题, 2017 年, Wei 等 ${ }^{[29]}$ 首次制备了无机配体配位的铜催化剂 $\left(\left(\mathrm{NH}_{4}\right)_{\mathrm{n}}[\mathrm{Cu}-\right.$ $\left.\mathrm{Mo}_{6} \mathrm{O}_{18}(\mathrm{OH})_{6}\right]$ ), 并将其用于催化醇和胺制备亚胺的反 应中 (Scheme 9). 对于茮醇和芐胺以及脂肪胺类底物, 以乙腈为溶剂, 在 $1 \mathrm{~mol} \%$ 催化剂和 $1 \times 10^{5} \mathrm{~Pa}$ 氧气 $50{ }^{\circ} \mathrm{C}$ 的条件下反应 $12 \mathrm{~h}$, 目标产物的产率在 $73 \%$ 97\%之间，该方法可以避免使用贵重金属和昂贵的、有 毒的、对水敏感的有机配体, 减少了对环境的危害, 符 合绿色化学发展思路, 为催化剂的开发提供了一种新的 思路. 其催化机理如 Scheme 10 所示.

\section{3 锰类催化剂}

2001 年, Taylor 等 ${ }^{[30]}$ 以活性二氧化锰作为原位氧化 剂氧化醇和胺制备亚胺 (Scheme 11). 对于芐醇类底物与 胺的反应，芳环上取代基的电性对反应基本没有影响; 二元醇也可以有效地转化为双亚胺. 但是该方法反应时 间较长且需要过量的氧化剂, 而且从严格意义来说该方 法不属于催化反应.

2008 年, Steven 等 ${ }^{[31]}$ 制备了锰八面体分子篮催化剂 (K-OMS-2), 并将其用于催化醇和胺偶联制备亚胺的反 应. 在空气存在下, 醇 $(1 \mathrm{mmol})$ 、胺 $(2 \mathrm{mmol})$ 和 K-OMS-2 $\left(50 \mathrm{mg}\right.$ ) 在甲苯中 $110{ }^{\circ} \mathrm{C}$ 反应 $12 \sim 24 \mathrm{~h}$, 原料转化率为

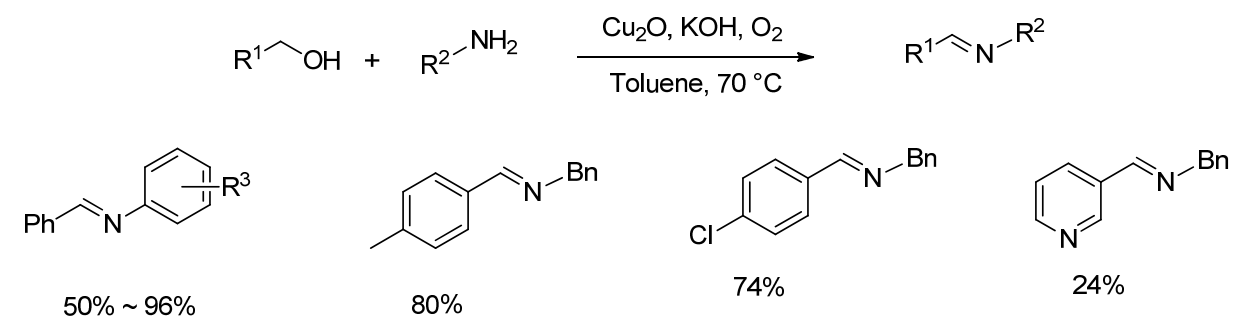

图式 6 荔枝型氧化亚铜 $\left(\mathrm{Cu}_{2} \mathrm{O}\right)$ 纳米团聚体催化醇和胺合成亚胺的反应

Scheme 6 Direct coupling of alcohols and amines catalyzed by uniform litchi shaped $\mathrm{Cu}_{2} \mathrm{O}$ nanoaggregates

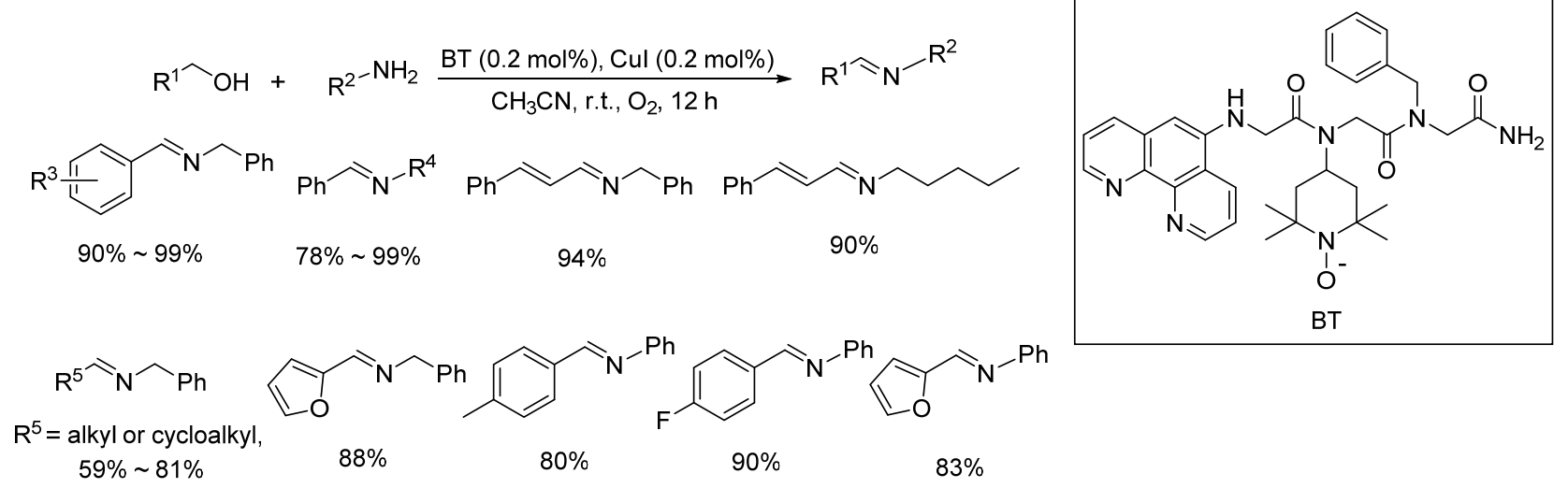

图式 7 BT 与碘化亚铜组成的催化剂催化醇和胺生成亚胺的反应

Scheme 7 Direct coupling of alcohols and amines catalyzed by BT and CuI 


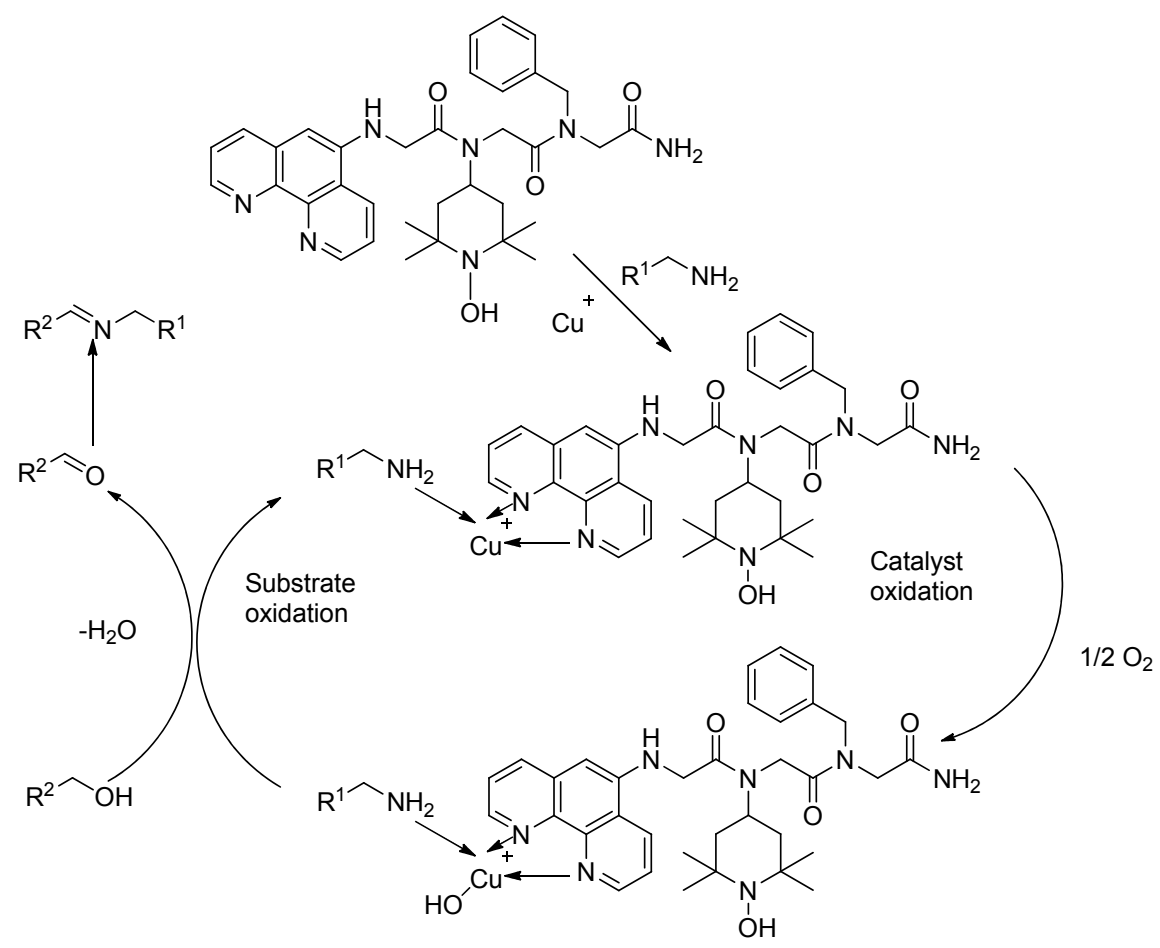

图式 $8 \mathrm{BT}$ 和 $\mathrm{CuI}$ 催化醇和胺合成亚胺的反应机理

Scheme 8 Proposed mechanism for the catalytic oxidative synthesis of imines catalyzed by BT and CuI

$$
\text { ( }
$$
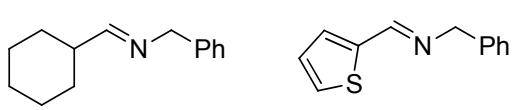

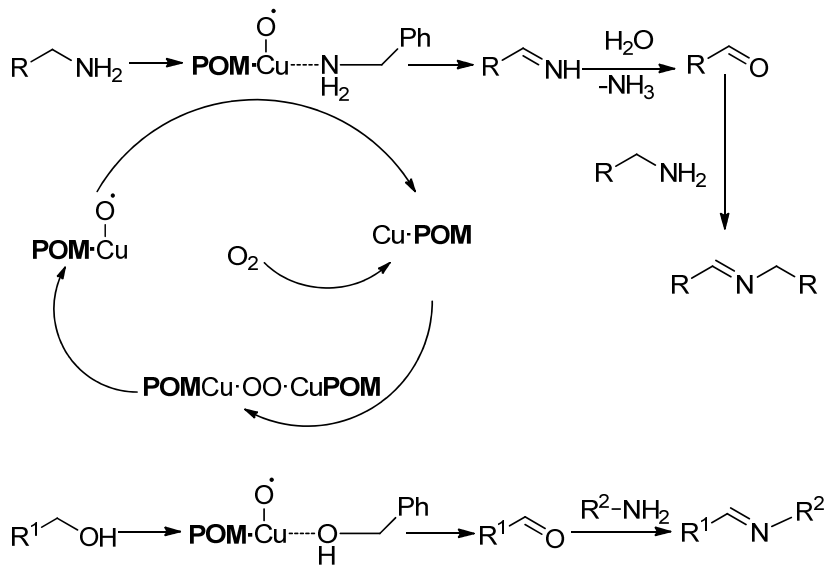

图式 10 无机配体配位铜催化醇和胺合成亚胺的反应机理

Scheme 10 Proposed mechanism for the direct coupling of alcohol and amine catalyzed by $\mathrm{Cu}$ complex

胺聚合物(DVTA)中，并将所得的复合材料用于催化空 气氧化 $\mathrm{sp}^{3}$ 杂化的 $\mathrm{C}-\mathrm{H}$ 键以及醇的选择性氧化, 聚合物 中嵌入八面体结构的纳米 $\mathrm{Mn}_{3} \mathrm{O}_{4}(\mathrm{Mn} @$ DVTA-3)催化活 性最好(Scheme 13). 该催化剂催化芳环上有不同取代 基的茮醇衍生物与芳香胺或茮胺的反应时，目标亚胺的 收率在 $80 \%$ ～ $88 \%$ 之间，而苯丙烯醇与苄胺反应的收率 为 $75 \%$. 总体来说催化效率不高, 但是该纳米金属催化 剂可以重复使用 4 次而锰不流失. 


$$
\mathrm{R}^{1} \widehat{\mathrm{OH}}^{+}+\mathrm{R}^{2}-\mathrm{NH}_{2} \underset{\mathrm{DCM}, \text { reflux, 24 48 h }}{\longrightarrow} \mathrm{R}^{1} \widehat{\mathrm{MnO}}_{\mathrm{N}}-\mathrm{R}^{2}
$$
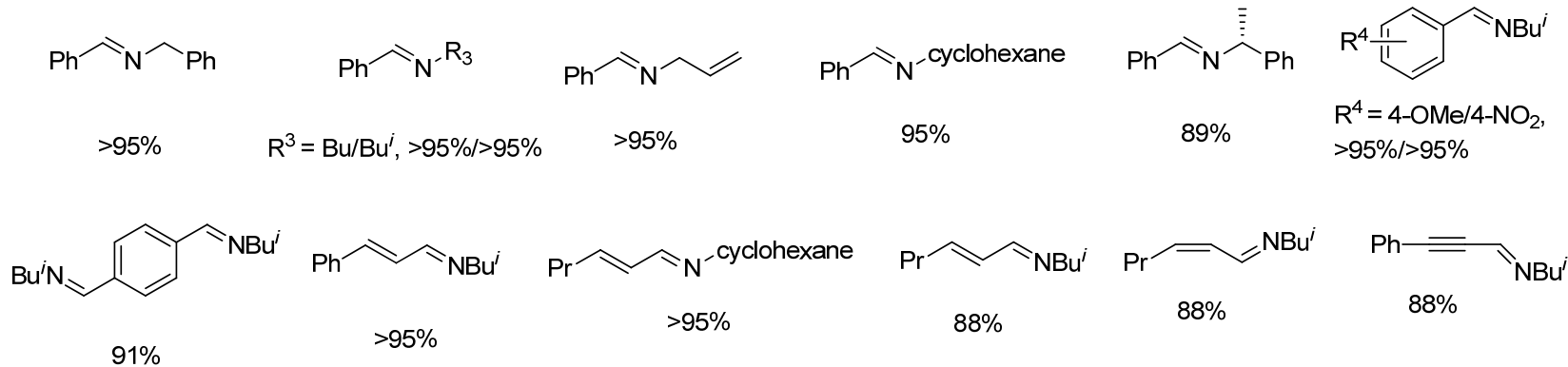

图式 $11 \mathrm{MnO}_{2}$ 催化醇和胺合成亚胺的反应

Scheme 11 Direct coupling of alcohols and amines catalyzed by $\mathrm{MnO}_{2}$

$$
\begin{aligned}
& \mathrm{R}^{1} \widehat{\mathrm{OH}}+\mathrm{R}^{2}-\mathrm{NH}_{2} \frac{\mathrm{K}-\mathrm{OMS}-2 \text {, toluene }}{110^{\circ} \mathrm{C}, \text { reflux, } 12 \text { or } 24 \mathrm{~h}} \mathrm{R}^{1} \widehat{N}^{-} \mathrm{R}^{2} \\
& \mathrm{Ph}^{-} \mathrm{N}^{-\mathrm{R}^{3}} \\
& \mathrm{R}^{3}=\mathrm{Bu} / \mathrm{Ph}, \text { Con. }=100 \% / 100 \%, \quad \text { Con. }=100 \% / 100 \% \text {, } \\
& \text { Sel. }=99 \% / 100 \%
\end{aligned}
$$
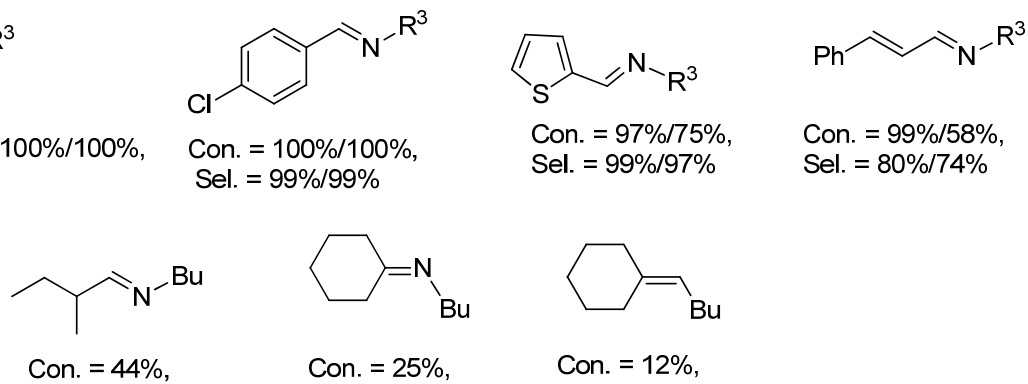

图式 12 八面体分子笁催化剂催化醇和胺合成亚胺的反应

Scheme 12 Direct coupling of alcohols and amines catalyzed by K-OMS-2

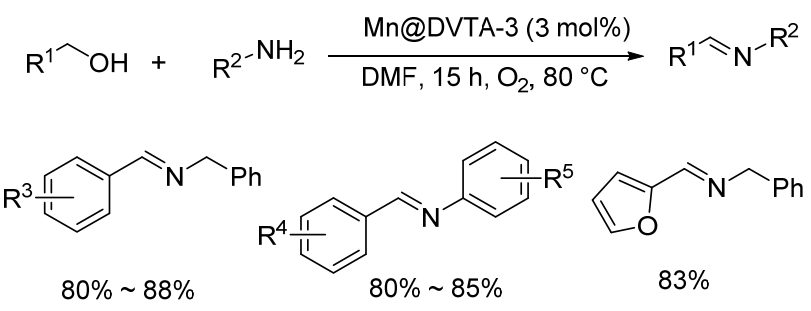

图式 13 Mn@DVTA-3 催化醇和胺制备亚胺的反应

Scheme 13 Direct coupling of alcohols and amines catalyzed by Mn@DVTA-3

同年, $\mathrm{Gao}$ 等 ${ }^{[33]}$ 将 $\mathrm{MnO}_{x}$ 负载于各种不同载体上, 发 现以羟磷灰石 (HAP) 为载体所制备的催化剂 $\left(\mathrm{MnO}_{x}\right.$ / HAP)在空气存在下具有良好的催化醇与胺偶联的性能. 对于茮醇类底物和苯胺的反应，该催化体系能以 $82 \%$ 98\%的收率得到相应的亚胺, 而长链的辛醇与苯胺在该 条件几乎不反应(Scheme 14). 该催化方法不需要添加 额外的助剂, 更为重要的是该催化剂易于回收且可重复 使用, 以茮醇和已胺为底物时, 催化剂在 9 次循环使用 时收率都达到了 $98 \%$, 并且可用于克级规模样品的制 备. 这两类锰催化剂的发现为设计廉价金属以及绿色高 效的多相催化剂开辟了一条新途径.

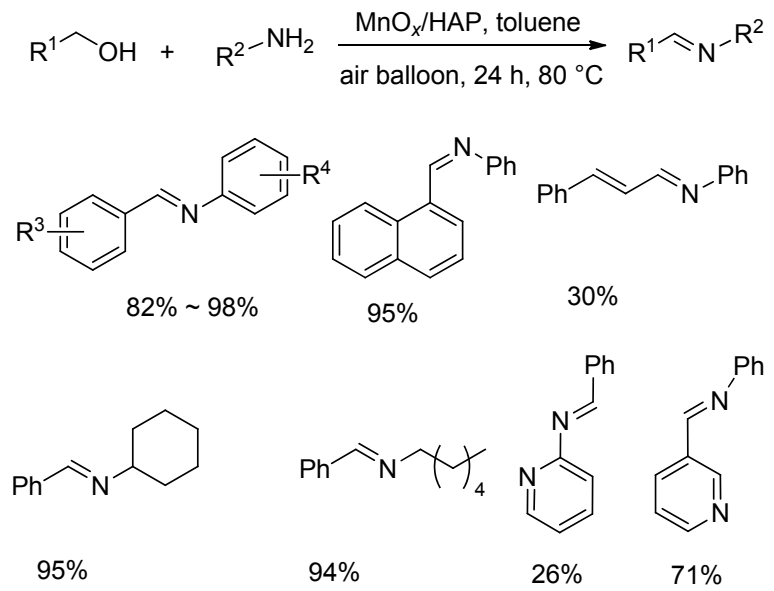

图式 $14 \mathrm{MnOx} / \mathrm{HAP}$ 催化醇和胺偶联制备亚胺的反应 Scheme 14 Direct coupling of alcohols and amines catalyzed by $\mathrm{MnOx} / \mathrm{HAP}$

\section{4 铁类催化剂}

2013 年, $\mathrm{Xu}$ 等 ${ }^{[34]}$ 报道了以空气为氧化剂, $\mathrm{Fe}\left(\mathrm{NO}_{3}\right)_{3}$ 、 $\mathrm{TEMPO}$ 以及氢氧化钾组成的体系催化不同 醇胺合成亚胺的方法(Scheme 15). 对于苄醇和苯胺类 底物，该方法以 $70 \% \sim 98 \%$ 的收率获得目标产物. 然而 对于茮醇和脂肪胺类底物，该方法收率较低(19\% 
$41 \%$ ), 长链醇与苯胺在该条件下几乎不反应. 该方法采 用空气作为氧化剂, 催化剂易获得, 反应条件较温和, 但反应体系中需要多种添加物且底物研究范围有限.

$$
\begin{aligned}
& \mathrm{R}^{1} \widehat{\mathrm{OH}}_{+} \mathrm{R}^{2}-\mathrm{NH}_{2} \underset{\text { Toluene, } \mathrm{KOH}, 36 \mathrm{~h} \text {, air, } 80^{\circ} \mathrm{C}}{\stackrel{\mathrm{C}}{\longrightarrow} \mathrm{N}_{3} / \mathrm{TEMPO}(10 / 10 \mathrm{~mol} \%)} \widehat{N}_{\mathrm{N}^{-}} \mathrm{R}^{2}
\end{aligned}
$$

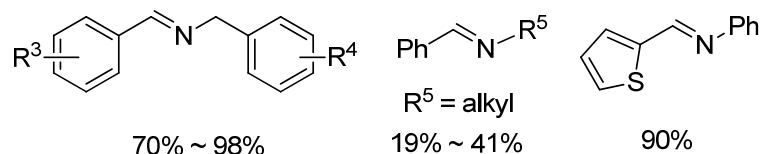

图式 $15 \mathrm{Fe}\left(\mathrm{NO}_{3}\right)_{3} / \mathrm{TEMPO}$ 催化醇和胺制备亚胺的反应 Scheme 15 Direct coupling of alcohols and amines catalyzed by $\mathrm{Fe}\left(\mathrm{NO}_{3}\right)_{3} / \mathrm{TEMPO}$

2016 年, Liu 等 ${ }^{[35]}$ 研制并报道了一种以介孔碳为载 体的 $\mathrm{FeO}_{x} / \mathrm{HCMK}-3$ 催化剂, 并将它用于催化醇和胺氧 化偶联生成亚胺的反应. 在 $100 \mathrm{kPa}$ 空气存在下, 醇(1 $\mathrm{mmol}$ )和胺 $(2 \mathrm{mmol}) 、 0.3 \mathrm{~g} \mathrm{FeO}_{x} / \mathrm{HCMK}-3$ 催化剂在甲苯 中 $80{ }^{\circ} \mathrm{C}$ 反应 $8 \mathrm{~h}$, 收率在 $64.2 \% \sim 98.0 \%$ 之间(Scheme 16). 芳环上连有供电子基团的茮醇类衍生物(如 4-甲 基、4-甲氧基和 4-异丙基)与苯胺反应时，分别以 93.2\%、 $90.7 \%$ 和 $84.2 \%$ 的收率得到目标产物. 脂肪胺(环己胺和
正丁胺)与苄醇反应, 能以较好的收率得到亚胺. 该催 化剂中高分散的 $\mathrm{FeO}_{x}$ 使 $\mathrm{FeO}_{x} / \mathrm{HCMK}-3$ 具有较高的还原 性和高的催化性能, 亚胺的形成过程经历了一个氧化还 原机理，三价铁在催化氧化醇为醛的同时，自身被还原 为二价铁, 二价铁又被氧氧化为三价, 从而实现了催化 剂的再生循环. 在亚胺的反应过程中, 醇的氧化脱氢反 应是整个反应的速率决定步骤.

\section{5 钉类催化剂}

2014 年, Ramesh 等 ${ }^{[36]}$ 在研究醇和胺反应制备亚胺 时, 以 $0.002 \mathrm{~mol} \% \mathrm{Ru}(\mathrm{II}) \mathrm{NNN}$ 配合物为催化剂, 在空气 存在下甲苯中 $70{ }^{\circ} \mathrm{C}$ 反应 $12 \sim 36 \mathrm{~h}$, 收率为 $41 \% \sim 96 \%$ (Scheme 17). 对于不同类型醇和胺类底物的反应，均能 以中等至良好的收率得到目标产物, 催化剂用量低且适 用范围较广, 并且可用于手性胺和氨基酸类底物与苄醇 的反应.

\section{6 金类催化剂}

负载型金纳米粒子作为有机转化催化剂越来越受 到人们的关注. 2009 年, $\mathrm{He}$ 等 ${ }^{[37}$ 制备了一种以羟基磷灰 石(HAP)为载体的金纳米粒子催化剂，并将其用于催化 醇和胺制备亚胺的反应. 在 $1 \mathrm{~mol} \%$ 金(以金的量计算)催

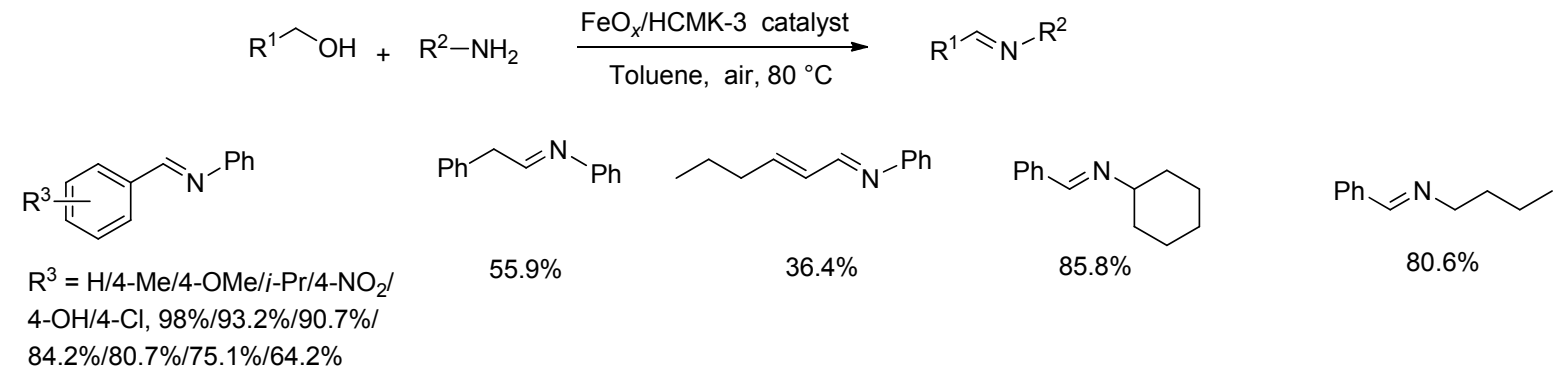

图式 $16 \mathrm{FeO}_{x} / \mathrm{HCMK}-3$ 催化醇和胺制备亚胺的反应

Scheme 16 Direct coupling of alcohols and amines catalyzed by $\mathrm{FeO}_{x} / \mathrm{HCMK}-3$

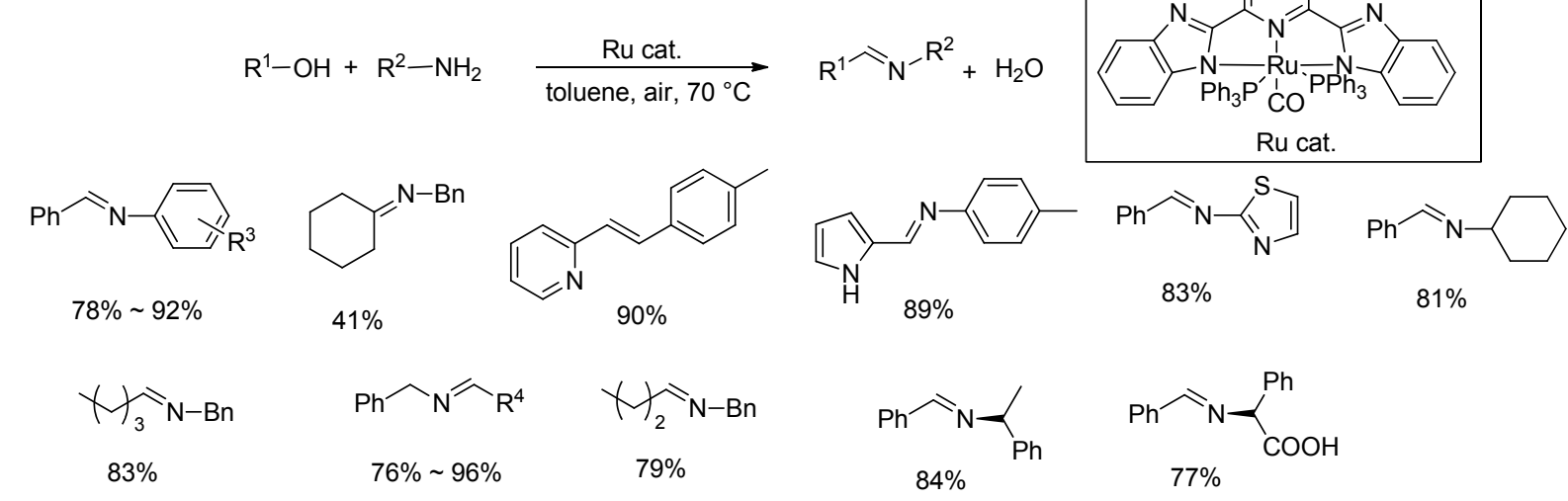

图式 $17 \mathrm{Ru}(\mathrm{II}) \mathrm{NNN}$ 配合物催化醇与胺偶联生成亚胺的反应

Scheme 17 Direct coupling of alcohols and amines catalyzed by Ru(II)NNN complex 
化剂和氧气存在下, 醇类和胺类底物在甲苯中 $60{ }^{\circ} \mathrm{C}$ 反 应 1 16 h, 底物醇的转化率在 $75 \% \sim 99 \%$ 之间, 目标产 物亚胺的选择性非常好, 在 $90 \% \sim 99 \%$ 之间, 其中芐醇 类底物的转化率为 76\% 99\%之间. 强吸电子基团的引 入(如硝基)会大大降低其转化率, 4-硝基苠醇的转化率 仅为 76\%, 长链烷基醇如正庚醇的转化率仅为 $75 \%$. 该 催化反应经历了一个醇先氧化为醛, 再和胺反应生成亚 胺的过程. 该催化剂为非均相催化剂, 金在催化过程中 不流失, 易回收, 且循环使用 5 次仍然保持活性. 金纳 米粒子的引入显著地改变了酸碱分布, 增加了 HAP 上 酸性和碱性位点的总数.

2010 年, Riisager 等 ${ }^{[38]}$ 报道了以二氧化钛 $\left(\mathrm{TiO}_{2}\right)$ 为载 体的金纳米粒子作为多相催化剂, 以纯氧为氧化剂催化 醇和胺反应生成亚胺的方法. 该反应在室温和常压下进 行，在适当的转化条件下，具有良好的选择性（> $98 \%)$, 但是醇类物质的转化率普遍较低 $(7 \% \sim 63 \%)$, 对 于常用作模型底物芐醇的反应，转化率也只有 $51 \%$.

2012 年, Hensen 等 ${ }^{[39]}$ 制备了一种在碱性水滑石 (HT) 负载金纳米粒子 (AuNP) 的非均相催化剂 $\mathrm{Au} /$ $\mathrm{Mg}_{2} \mathrm{Al}-\mathrm{HT}$, 并将其用于催化醇和胺反应制备亚胺. 在 $0.5 \mathrm{~mol} \%$ 催化剂和氧气存在下, 醇和胺类底物在甲苯中 于 $60{ }^{\circ} \mathrm{C}$ 反应, 醇类底物的转化率和亚胺的选择性随着 反应时间的延长而增加, 反应时间为 $5 \sim 12 \mathrm{~h}$, 转化率
在 $77 \% \sim 100 \%$ 之间，选择性在 $63 \% \sim 100 \%$ 之间，该催 化剂明显优于前几种负载金纳米粒子的催化剂, 不仅提 高了化学合成的效率, 而且具有稳定性高、产物污染少、 催化剂易分离、易再利用的优点, 具有进一步研究和开 发的价值.

2013 年, Kobayashi 等 ${ }^{[40]}$ 报道了一种有效且可重复 使用的聚合物嵌顿的金/钯合金纳米粒子的 (PICB$\mathrm{Au} / \mathrm{Pd}$ )多相催化剂. 在 $1.5 \mathrm{~mol} \% \mathrm{PICB}-\mathrm{Au} / \mathrm{Pd} 、 25 \mathrm{~mol} \%$ 的氢氧化钠和氧气存在的条件下, 醇类和胺类底物在 $40{ }^{\circ} \mathrm{C}$ 或 $60{ }^{\circ} \mathrm{C}$ 的混合溶剂 $[V$ (四氢呋喃) $/ V$ (四氟乙烯 $)=$ $4: 1$ ]中反应 $12 \mathrm{~h}$, 目标产物亚胺的收率在 $58 \% \sim 95 \%$ 之 间，长链的正辛醇底物收率较低只有 $58 \%$, 其它醇类和 胺类底物收率均较好(Scheme 18). PICB-Au/Pd 非均相 催化剂具有较好的活性和选择性, 且可以容易地多次循 环而不损失活性, 但反应需要强碱氢氧化钠的参与.

2017 年, Wang 等 ${ }^{[41]}$ 将 2-吡啶基苯并三唑与金(III) 配位合成了吡啶基三唑金(III)配合物 TA-Py-Au(III), 并 将该配合物作为催化剂用于催化醇和胺合成亚胺的反 应. 在 $1 \mathrm{~mol} \%$ 催化剂、 $120 \mathrm{~mol} \% \mathrm{KOH}$ 和空气存在下, 醇和胺在甲苯中回流反应 $24 \mathrm{~h}$, 亚胺产物的收率为 $76 \% \sim 94 \%$ (Scheme 19). 对于芐醇和芳胺类底物，当芳 环上取代基为 $\mathrm{F} 、 \mathrm{Cl} 、 \mathrm{OMe}$ 和 $\mathrm{Me}$ 时，亚胺的产率较高; 且具有吡啶基或呋喃基的底物也适用于这一反应. 该催

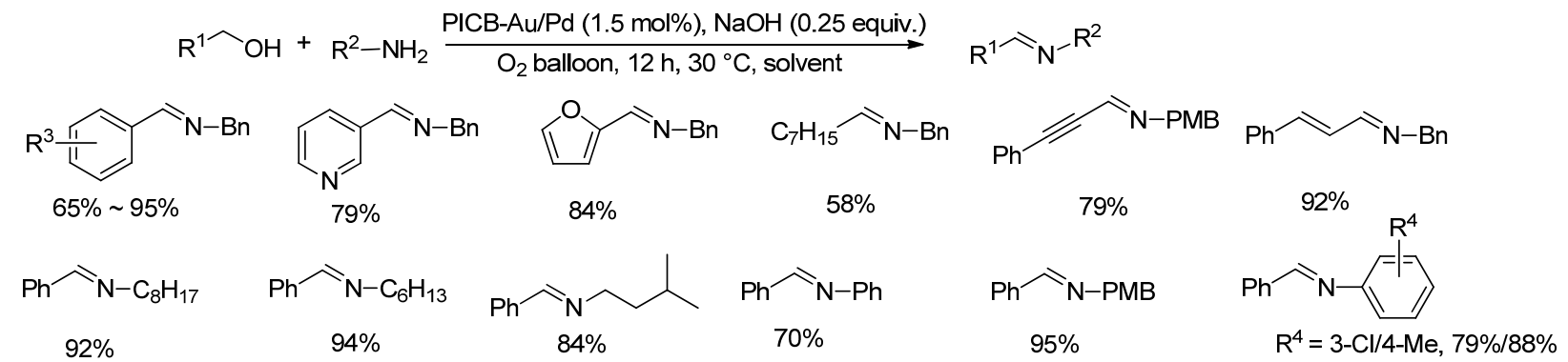

图式 $18 \mathrm{PICB}-\mathrm{Au} / \mathrm{Pd}$ 多相催化剂催化醇与胺偶联生成亚胺的反应

Scheme 18 Direct coupling of alcohols and amines catalyzed by PICB-Au/Pd

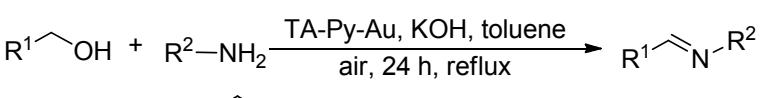

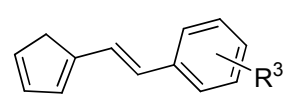

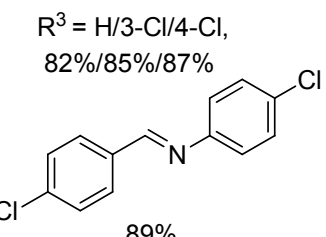

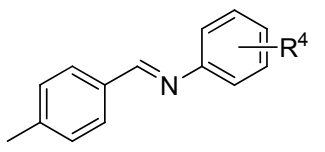

$\mathrm{R}^{4}=\mathrm{H} / 3-\mathrm{Cl} / 4-\mathrm{Cl} / 4-\mathrm{OMe}$, $94 \% / 92 \% / 81 \% / 78 \%$<smiles>C(=N/c1ccccn1)\c1ccccc1</smiles>

$88 \%$<smiles>C(=N/c1ccccc1)\c1ccccc1</smiles>

$\mathrm{R}^{5}=2-\mathrm{Cl} / 3-\mathrm{Cl} / 4-\mathrm{Cl} / 4-\mathrm{OMe} / 4-\mathrm{F}$, $83 \% / 81 \% / 85 \% / 84 \% / 76 \%$<smiles>O=C(/N=C/c1ccccc1)OC(=O)OCc1ccc(Cl)cc1</smiles>

$89 \%$

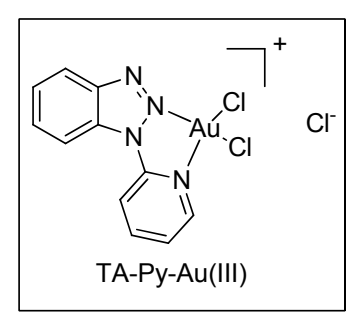

TA-Py-Au(III)

图式 19 TA-Py-Au(III)催化剂催化醇与胺偶联生成亚胺的反应

Scheme 19 Direct coupling of alcohols and amines catalyzed by TA-Py-Au(III) 
化剂中加入了一个配位能力强的配体, 大大提高了催化 剂的活性, 有助于该催化剂在高温下分解成金纳米粒子 而延迟聚集, 更为重要的是该催化剂对空气和水分不敏 感且可催化炔丙醚的 3,3-重排制备丙二烯类化合物.

\section{7 银类催化剂}

2014 年, Jiang 课题组 ${ }^{[42]}$ 在研究醇的选择性氧化时 发现, 银一氮杂环卡宾 (NHC)复合物具有优异的催化醇 胺偶联制备亚胺的性能. 在 $0.1 \mathrm{~mol} \%$ 催化剂、 1.1 equiv. $\mathrm{BnMe}_{3} \mathrm{NOH}(\mathrm{BTMAH}) 、 4 \AA$ 分子篎和干燥的空气存在 下, 醇和胺类底物在甲苯中常温反应 $12 \mathrm{~h}$, 以 $80 \%$ 99\%的收率得到目标产物(Scheme 20). 对于苠醇类与茮 胺类或苯胺类底物，目标产物的收率在 $82 \% \sim 98 \%$ 之间. 芐醇与环己胺或正丙胺的反应收率分别为 $97 \%$ 和 $98 \%$. 该催化方法底物应用范围广, 反应条件温和, 产物收率 高, 是一种非常有效的亚胺制备方法. 催化机理如图 (Scheme 21)所示.

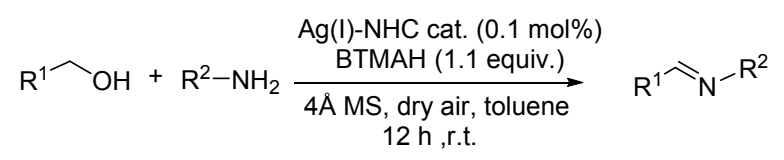

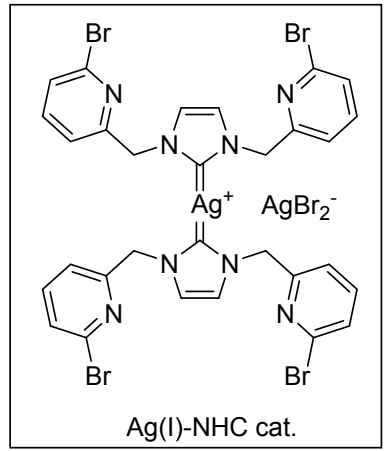

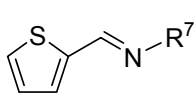

$\mathrm{R}^{5} \frac{1}{\mathrm{~N}-\mathrm{Bn}}$

$87 \% \sim 98 \%$

$82 \% \sim 99 \%$<smiles>[R]N=Cc1ccco1</smiles>

$\mathrm{R}^{7}=\mathrm{Ph} / \mathrm{Bn}, 83 / 85 \%$<smiles></smiles>

$91 / 90 \%$<smiles>[R]N=C/C=C(\C)CCC=C(C)C</smiles>

$83 / 85 \%$

图式 $20 \mathrm{Ag}-\mathrm{NHC}$ 催化剂催化醇与胺偶联生成亚胺的反应

Scheme 20 Direct coupling of alcohols and amines catalyzed by Ag-NHC catalyst

2014 年, Kegnæs 等 ${ }^{[43]}$ 将银 $(\mathrm{Ag})$ 负载在氧化铝 $\left(\mathrm{Al}_{2} \mathrm{O}_{3}\right)$ 上制备了负载的银纳米粒子催化剂 $\left(\mathrm{Ag} / \mathrm{Al}_{2} \mathrm{O}_{3}\right)$,
并将其用于催化醇和胺制备亚胺的反应. 在 $5 \mathrm{wt} \%$ 的催 化剂和空气条件下，醇和胺类物质在甲苯中 $100{ }^{\circ} \mathrm{C}$ 反 应 $24 \mathrm{~h}$, 目标亚胺产物的收率在 $16 \% \sim 81 \%$ 之间. 对于 常用的模板底物芐醇和芐胺的反应，茮醇的转化率只有 $10 \%$ ，虽然其选择性为 $99 \%$ ，但产物收率只有 $10 \%$. 当 采用正已醇为底物时, 基本上不发生转化. 总体来说, 该催化剂催化效率较低, 底物适用范围有限。

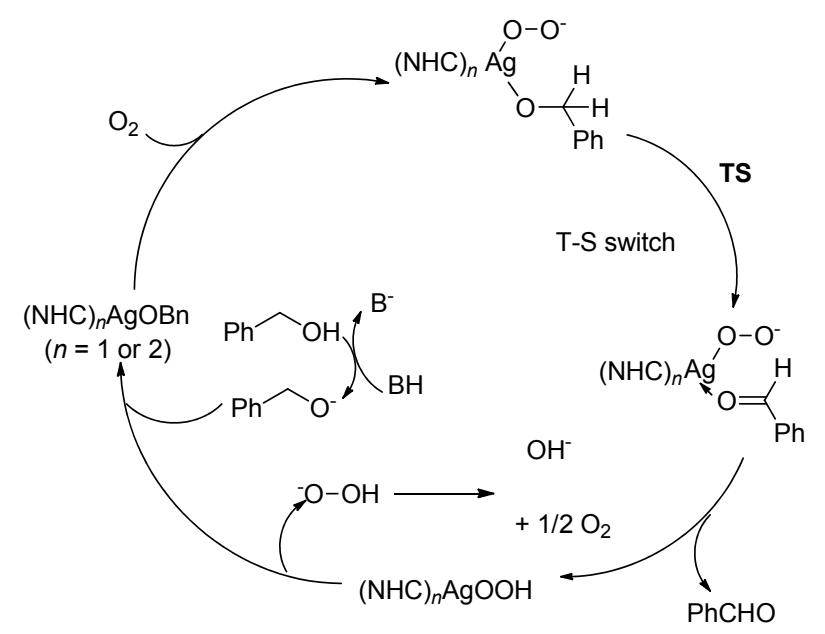

图式 $21 \mathrm{Ag}-\mathrm{NHC}$ 催化剂催化醇与胺偶联生成亚胺可能的反 应机理

Scheme 21 Possible mechanism of imine formation catalyzed by Ag-NHC catalyst

\section{2 醇与胺的脱氢缩合}

\section{1 钴类催化剂}

2013 年, Hanson 等 ${ }^{[4]}$ 将一种均相的金属钴催化剂 用于催化醇和胺偶联合成亚胺(Scheme 22). 気标记研 究表明, 反应经历了醇脱氢的过程. 对于催化亚胺化, 钴具有与贵金属催化剂相当的活性, 并且对一系列苄醇 与脂肪族胺以及脂肪醇与脂肪胺的反应都是有效的, 目 标亚胺产物的收率在 56\% 99\%之间. 对于部分底物会 有少量亚胺双键被还原. 该催化方法突出了钴作为贵金 属钓、铱和锇催化剂替代品的潜力.

2013 年, Xia 等 ${ }^{[45]}$ 采用阴离子交换法将钴离子交换 到沸石中制备了钴沸石催化剂, 并首次将其用于醇直接 烷基化芳香胺的反应中(Scheme 23). 在最佳条件下芐 醇对苯胺的烷基化反应中苯胺的转化率为 $89.8 \mathrm{~mol} \%$. 钴的负载量、载体、温度和碱等因素对反应均有较大影 响, 该催化剂在反应完毕后仍保持多孔结构并具有稳定 的催化活性. 该催化剂整体活性较低且对底物适应性的 研究较少, 无法明确其可能的底物适用范围.

2018 年, Balaraman 等 ${ }^{[46]}$ 报道了一种不含膦配体的 Co(II)-NNN 钳子型配合物, 并将其作为催化剂用于催 


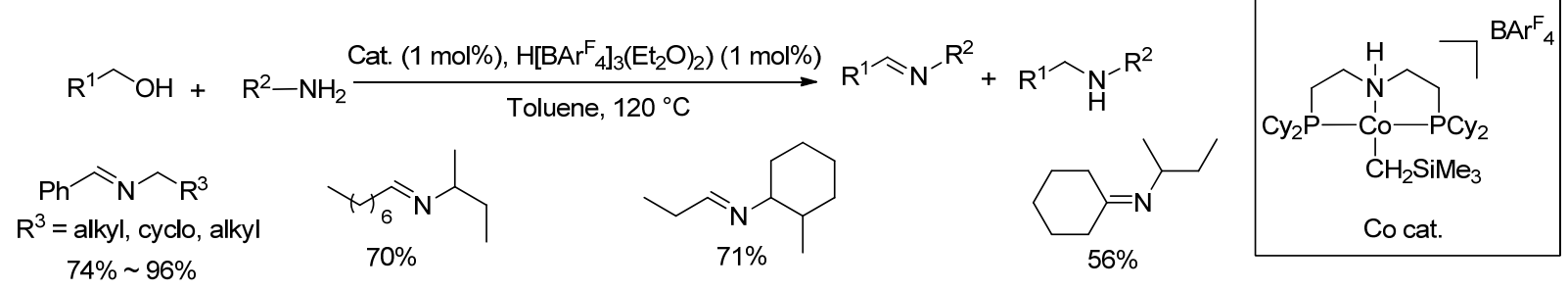

图式 22 富土金属催化剂钴催化醇和胺偶联制备亚胺的反应

Scheme 22 Direct coupling of alcohols and amines catalyzed by Co complex

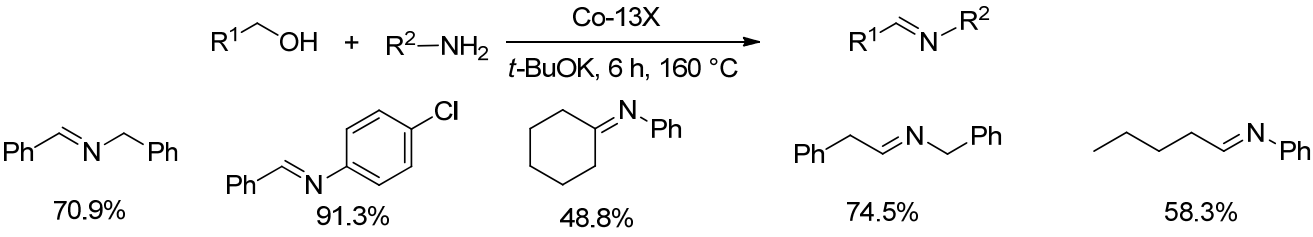

图式 23 钴沸石催化剂催化醇和胺偶联制备亚胺的反应

Scheme 23 Direct coupling of alcohols and amines catalyzed by cobalt zeolite catalyst

化醇和胺脱氢偶联生成亚胺的反应. 在 $4 \AA$ 分子篮、 5 $\mathrm{mol} \%$ 催化剂和 $110 \mathrm{~mol} \%$ 叔丁醇钾存在下, 醇和胺类底 物在正辛烷中 $150{ }^{\circ} \mathrm{C}$ 反应 $32 \mathrm{~h}$ ，亚胺收率为 $72 \% \sim 84 \%$ (Scheme 24). 对于各种含供电子和吸电子取代基的苄 胺和苄醇, 该方法都能以较好的收率得到亚胺产物。虽 然该反应的副产物只有水和氢气，但需要过量的碱.

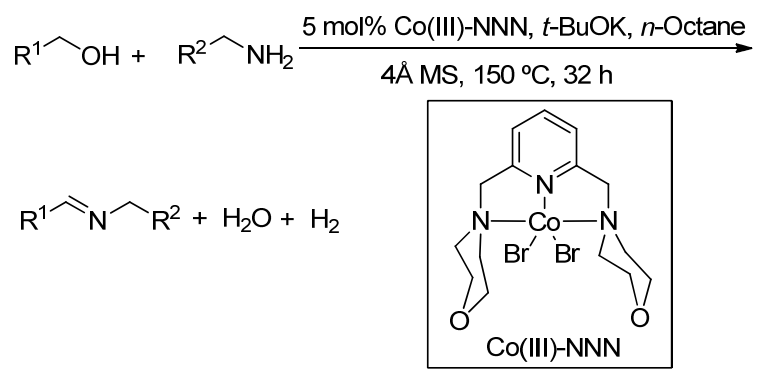

$$
\begin{aligned}
& \mathrm{R}^{3}=\mathrm{H} / 4-\mathrm{Me} / 4-\mathrm{F} / 3-\mathrm{Cl} / 2-\mathrm{CF}_{3}, \\
& 84 \% / 80 \% / 77 \% / 79 \% / 72 \%
\end{aligned}
$$

图式 $24 \mathrm{Co}(\mathrm{II})-\mathrm{NNN}$ 型配合物催化醇与胺偶联制备亚胺 Scheme 24 Direct coupling of alcohols and amines catalyzed by $\mathrm{Co}(\mathrm{II})-\mathrm{NNN}$ complex

\section{2 铱类催化剂}

2011 年, Pullarkat 等 ${ }^{[47]}$ 制备了一种 $\left[\mathrm{Cp} * \operatorname{Ir}\left(\eta^{3}\right.\right.$-tpdt $\left.)\right]$ 配合物，并将其用于催化醇和胺制备亚胺(Scheme 25). 该方法以 $1 \mathrm{~mol} \%$ 铱配合物为催化剂, 1 equiv.氢氧化钾 为碱, 醇和胺在甲苯中 $110{ }^{\circ} \mathrm{C}$ 反应 $45 \sim 68 \mathrm{~h}$, 目标产物 亚胺的收率与底物的类型相关性较大，收率在 9\% 100\%之间. 对于芐醇、4-甲氧基芐醇与芐胺以及异丙胺 的反应，该催化体系能以几乎定量的产率得到目标产
物; 而对于茮醇与苯胺的反应，目标产物收率较低，只 有 $9 \%$, 主要副产物是亚胺被还原为苯基茮基胺. 该催 化剂在催化过程中需要使用 1 equiv.的氢氧化钾且研究 的反应底物有限，该方法对底物官能团的耐受性尚不清 晰，总体来说，该催化体系反应时间偏长，催化剂催化 效率不高

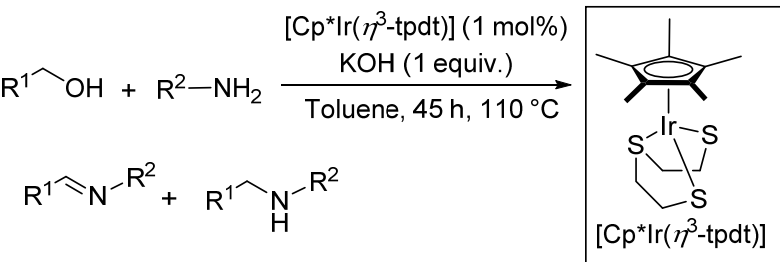

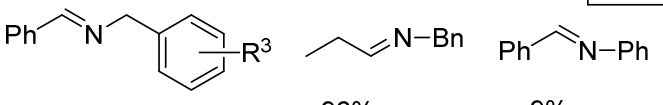

$$
\begin{aligned}
& 86 \% \sim 100 \% \quad 96 \% \quad 9 \%
\end{aligned}
$$

图式25 $\left[\mathrm{Cp} * \operatorname{Ir}\left(\eta^{3}-\mathrm{tpdt}\right)\right]$ 配合物催化醇与胺偶联生成亚胺的 反应

Scheme 25 Direct coupling of alcohols and amines catalyzed by $\left[\mathrm{Cp} * \operatorname{Ir}\left(\eta^{3}-\mathrm{tpdt}\right)\right]$ complex

2016 年, Ozawa 等 ${ }^{[48]}$ 制备了含去芳香化吡啶环的 PNP 钳形磷烯配体(PPEP*)的 Ir 配合物 $\left[\operatorname{IrPPh}_{3}\left(\mathrm{PPEP}^{*}\right)\right]$, 并研究了其催化醇烷基化胺的反应(Scheme 26). 在 1 $\mathrm{mol} \%$ 铱配合物和氮气氛围下，醇和胺类底物在甲苯中 回流反应 $24 \mathrm{~h}$ ，产物亚胺的产率在 4\% 93\%之间，同时 会产生部分亚胺双键还原的副产物.

\section{3 钉类催化剂}

2010 年, Milstein 等 ${ }^{[49]}$ 以均相的 PNP 型钓鳌合物催 化醇和胺脱氢缩合制备亚胺，在 $0.2 \mathrm{~mol} \%$ 催化剂和氩气 存在下，醇和胺在甲苯中回流反应 $22 \sim 56 \mathrm{~h}$ ，亚胺 


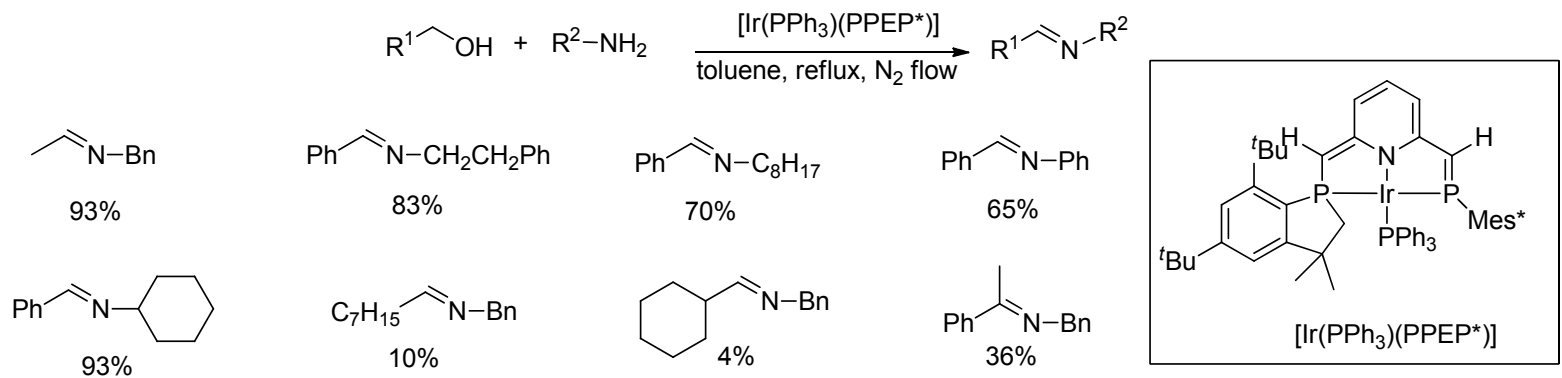

图式 26 含去芳化 PNP 钳型磷烯配体(PPEP*)的 Ir 配合物催化醇与胺偶联生成亚胺的反应

Scheme 26 Direct coupling of alcohols and amines catalyzed by Ir complexes

收率在 20\% 92\%之间(Scheme 27). 芐醇类底物与芐胺 或脂肪胺反应能以 $77 \% \sim 92 \%$ 的产率得到亚胺. 链状的 正己醇、正戊醇或正丁醇与苄胺或脂肪胺反应虽能以 $57 \% \sim 86 \%$ 的收率得到产物, 但体系中会产生一定量的 酰胺和酯; 环己醇与芐胺的反应收率只有 $20 \%$. 总体来 说, 该方法对茮醇类底物与茮胺和脂肪胺的反应催化效 果较好; 对于脂肪醇类底物与胺的反应, 会产生一定量 的酰胺和酯等副产物. 该催化方法催化剂用量少, 转化 数高, 除了氢气和水之外几乎无其它废弃物生成, 且反 应过程中亚胺不会被生成的副产物氢气还原; 但该催化 剂的制备以及回收相对较为困难, 且亚胺收率仍然有较 大的提高空间.

2011 年, Ramón 等 ${ }^{[50]}$ 将钓浸渍在磁铁矿上制备了一 种新型催化剂 $\left(\mathrm{Ru}(\mathrm{OH})_{3}-\mathrm{Fe}_{3} \mathrm{O}_{4}\right)$, 并将其用于催化醇对弱 亲核性的氨基衍生物(芳胺、磺酰胺、磺胺)的烷基化反 应; 当芳胺类底物和醇反应时, 依据所用碱的不同, 会 以不同比例得到亚胺和亚胺双键被还原的 (二级胺)产 物.当采用氢氧化钠为碱时, 在 $1.3 \mathrm{~mol} \%$ 催化剂和氩气 存在下，醇和芳胺在甲苯中 $130{ }^{\circ} \mathrm{C}$ 反应 $24 \mathrm{~h}$ ，以 $77 \%$
91\%的收率得到目标亚胺产物(Scheme 28). 利用其磁 性, 该催化剂回收容易; 催化剂回收后可循环使用十次.

2012 年, Madsen 等 ${ }^{[5]}$ 制备了一种新的钓杂环卡宾 配合物 $\left[\mathrm{RuCl}_{2}\left(\mathrm{I}^{\mathrm{I}} \mathrm{Pr}\right)(p\right.$-cymene)]催化剂, 并将其用于催化 有位阻的胺和醇直接脱氢偶联制备亚胺. 在 $4 \AA$ 分子 篮、 $5 \mathrm{~mol} \%$ 催化剂、 $10 \mathrm{~mol} \% \mathrm{DABCO}$ 和氮气存在下, 醇 和胺类底物在甲苯中回流反应 $24 \mathrm{~h}$, 亚胺的收率为 $33 \% \sim 80 \%$ (Scheme 29). 其中, 邻羟基苠醇与叔辛胺反 应收率只有 $33 \%$, 其它茮醇类底物与叔辛胺的收率在 $48 \% \sim 80 \%$ 之间，其中以芐醇与叔辛胺反应收率为最高 $(80 \%)$, 芳环上取代基位置及类型对收率影响的规律不 明显. 贲醇与环己胺、1-金刚烷胺反应的收率分别为 $60 \%$ 和 70\%; 光学纯 $(R)$-1-苯基乙胺和 $(R)-1$-(1-菜基)乙 胺与茮醇反应过程中不发生消旋; 大位阻的三苯甲胺与 茮醇反应时，虽然茮醇的转化率达到了 $75 \%$ ，却没有目 标产物生产, 主要产物是茮醇自身缩合形成的苯甲酸茮 酯. 通过氛标记实验发现, 初始的醇 $\beta$-位脱氢至醛的过 程是个可逆过程，活性催化组分为二氢钓化物. 其反应

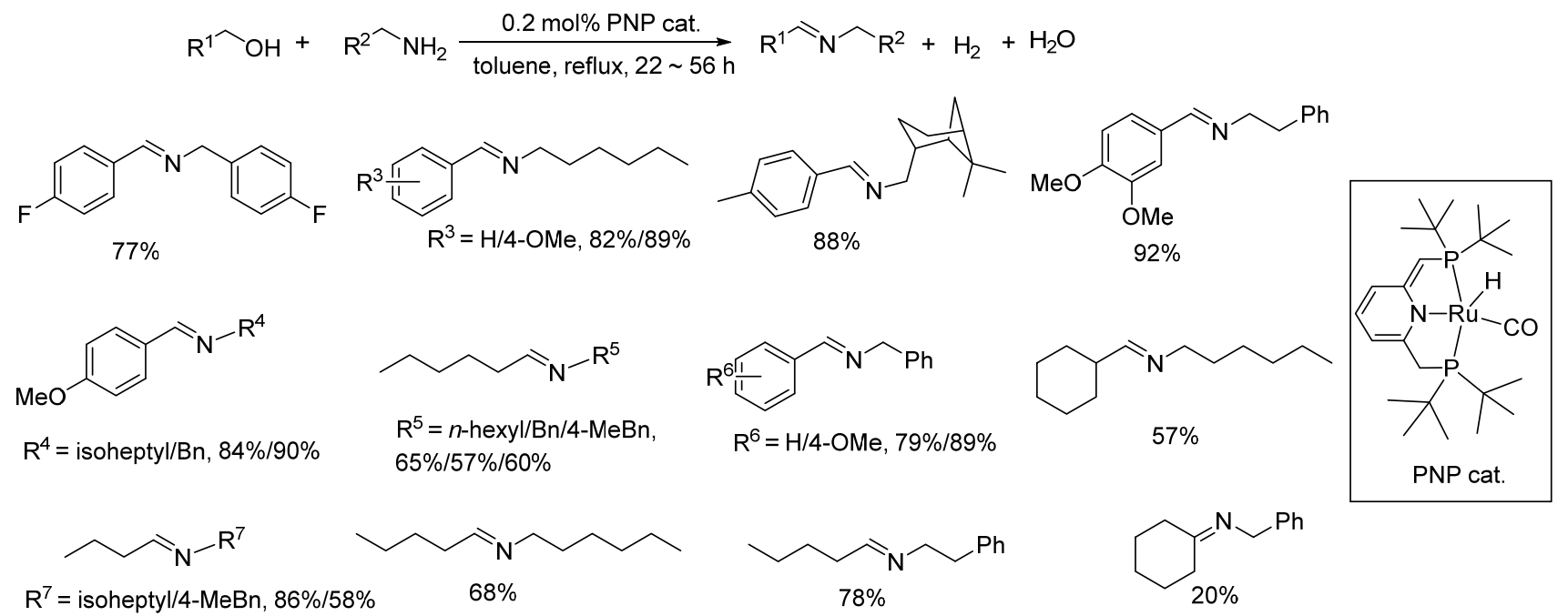

图式 27 均相钉螯合物催化醇与胺偶联生成亚胺的反应

Scheme 27 Direct coupling of alcohols and amines catalyzed by PNP-type ruthenium pincer complex 


$$
\begin{aligned}
& \mathrm{R}^{1}-\mathrm{NH}_{2}+\mathrm{R}^{2} \widehat{\mathrm{OH}}_{\frac{\mathrm{Ru}(\mathrm{OH})_{3}-\mathrm{Fe}_{3} \mathrm{O}_{4}(1.3 \mathrm{~mol} \%)}{\mathrm{NaOH}(130 \mathrm{~mol} \%), \text { toluene }}} \mathrm{R}^{1}-\mathrm{N}^{\circ{ }^{\circ} \mathrm{C}, 24 \mathrm{~h}} \\
& \overbrace{\mathrm{Nh}}^{1} \mathrm{R}^{3} \\
& \mathrm{~N}^{4}-\mathrm{Ph}
\end{aligned}
$$

$\mathrm{R}^{3}=\mathrm{H} / 4-\mathrm{OMe} / 3-\mathrm{Cl}, 89 \% / 91 \% / 77 \% \quad \mathrm{R}^{4}=4-\mathrm{OMe} / 4-\mathrm{Cl}, 83 \% / 79 \%$

图式 $28\left(\mathrm{Ru}(\mathrm{OH})_{3}-\mathrm{Fe}_{3} \mathrm{O}_{4}\right)$ 催化醇和胺偶联制备亚胺的反应 Scheme 28 Direct coupling of alcohols and amines catalyzed by $\mathrm{Ru}(\mathrm{OH})_{3}-\mathrm{Fe}_{3} \mathrm{O}_{4}$

$$
\mathrm{R}^{1} \widehat{\mathrm{OH}}+\mathrm{R}^{2}-\mathrm{NH}_{2} \frac{\begin{array}{c}
5 \mathrm{~mol} \% \mathrm{RuCl}_{2}\left(\mathrm{I}^{\prime} \mathrm{Pr}\right)(p \text {-cymene }) \\
4 \AA \mathrm{MS}, \text { toluene, } 110^{\circ} \mathrm{C}, 24 \mathrm{~h}
\end{array}}{10 \mathrm{~mol} \% \text { DABCO }} \mathrm{R}^{1} \widehat{N}^{-}-\mathrm{R}^{2}
$$
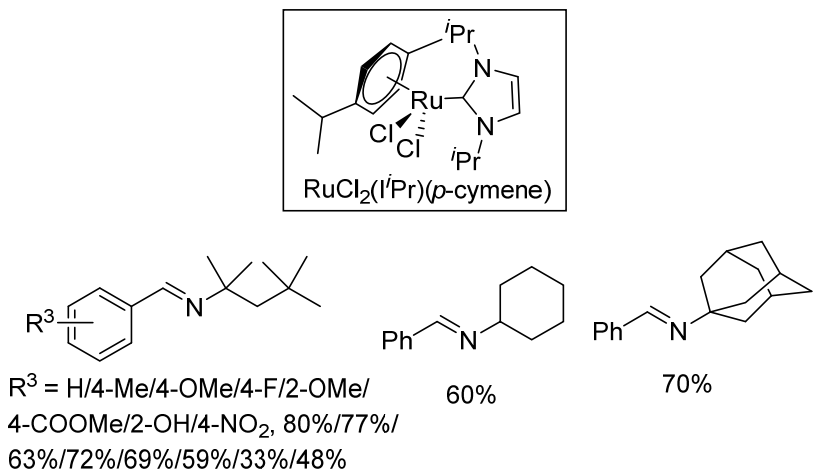<smiles>CC(N=Cc1ccccc1)c1cccc2ccccc12</smiles>

$52 \%$<smiles>CCCCCC=NC1(C)CC(C)(C)C1</smiles><smiles>C(=Nc1ccccc1)c1ccccc1</smiles>

图式 $29\left[\mathrm{RuCl}_{2}\left(\mathrm{I}^{i} \mathrm{Pr}\right)(p\right.$-cymene $\left.)\right]$ 催化醇与胺偶联生成亚胺的 反应

Scheme 29 Direct coupling of alcohols and amines catalyzed by $\mathrm{RuCl}_{2}\left(\mathrm{I}^{i} \mathrm{Pr}\right)(p$-cymene)

机理是醇在催化剂作用下脱氢生成醛与催化剂的配合 物, 然后胺亲核攻击醛与钉催化剂形成的配合物形成半 胺醛, 半胺醛从催化剂脱离后脱水生成亚胺. 该催化方 法操作简单, 副产物只有水和氢气, 但反应收率不高. 由于作者只研究了有位阻的胺类与醇的亚胺化反应, 因 此无法推测小位阻胺类与醇类的反应效果.

2012 年, Schomaker 等 ${ }^{[52]}$ 以 PNN 型钉螯合物为催化 剂, 研究了其催化烯丙基醇类和胺类底物直接脱氢偶联 制备 $\alpha, \beta$-不饱和亚胺的方法. 在 $1 \mathrm{~mol} \%$ 催化剂和氮气氛 围下, 烯丙基醇和胺类底物在甲苯中回流反应 $24 \mathrm{~h}, \alpha, \beta$ 不饱和亚胺产物收率为 15\% 83\% (Scheme 30). 3-甲基2-丁烯一烯醇和富电子的伯胺反应时 $\alpha, \beta$-不饱和亚胺的 产率较好; 当与弱亲核性的苯胺反应时, 则收率较低.
重要的是烯丙醇类底物结构中其它孤立的双键在反应 体系中不会被还原，且体系中的双键在反应条件下也不 会发生明显的迁移. 该催化方法针对烯丙醇类与胺类底 物直接偶联, 无需任何其它添加剂, 虽然总体来说收率 不高, 但属首次且较为系统和深入, 为进一步研究该类 底物的反应提供了很好的借鉴.

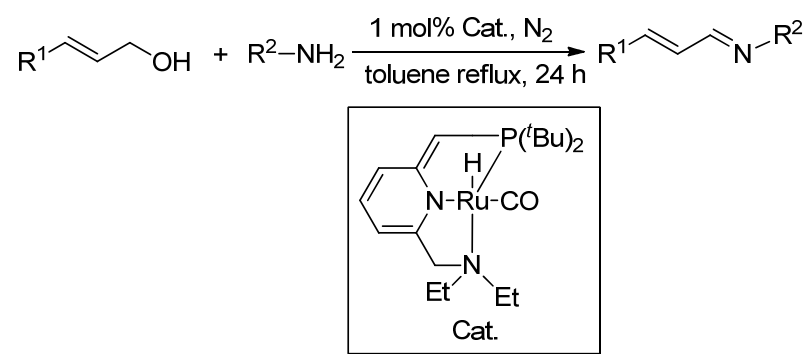<smiles>[R][R]c1ccc(CN=CC=C(C)C)cc1</smiles><smiles>CC(C)=CC=NC1CCCCC1</smiles>

$77 \%$<smiles>CC(C)C/C=C/C=N/Cc1ccccc1</smiles>

$26 \%$<smiles>C=C(C)C1CC=C(C=NCc2ccccc2)CC1</smiles>

$70 \%$<smiles>CC(C)=CC=Nc1ccccc1</smiles>

$22 \%$<smiles></smiles>
$49 \%$

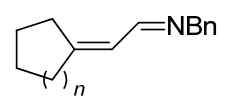

$n=1,15 \% ; n=2,38 \%$<smiles>CC(C)=CC=NC(C)c1ccccc1</smiles>

$74 \%$

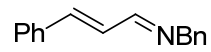<smiles>CC(=CC=[Nb])C(C)C</smiles>

$61 \%$
图式 30 钉催化剂催化醇与胺偶联生成亚胺的反应 Scheme 30 Direct coupling of alcohols and amines catalyzed by ruthenium complex

2013 年, Gelman 等 ${ }^{[53]}$ 报道了含二苯并苯二烯配体 结构片段的双官能化的新型钉配合物，该配合物在空气 中稳定，具有良好的催化醇无受体脱氢生成酯和醇以及 胺无受体脱氢偶联生成亚胺的活性. 在 $2 \mathrm{~mol} \%$ 催化剂 和 $5 \mathrm{~mol} \% \mathrm{DBU}$ 存在的条件下, 茮醇类和胺类底物在对 二甲苯中回流反应，以 $25 \% \sim 98 \%$ 的收率得到目标产物 (Scheme 31). 该催化剂对于大位阻的胺类如叔丁胺收 率较低, 只有 $25 \%$, 对于贲醇和苯胺以及芳胺类底物, 目标产物收率很高，达到了 $98 \%$.

2014 年, Bera 等 ${ }^{[54]}$ 报道了一种新型的双钉配合物, 并以其为催化剂研究了其催化醇和胺制备亚胺的性能 (Scheme 32). 在 $1 \mathrm{~mol} \%$ 催化剂、 $5 \mathrm{~mol} \% \mathrm{DABCO}$ 以及 $4 \AA$ 分子篮存在的条件下, 醇和胺在甲苯中回流反应 24 $\mathrm{h}$, 目标产物亚胺的收率在 $72 \% \sim 96 \%$ 之间. 该方法底物 适用范围较广，对于茮醇类与芳胺、茮胺以及脂肪胺的 反应, 目标亚胺产物的收率均较高, 对于脂肪醇类底物 


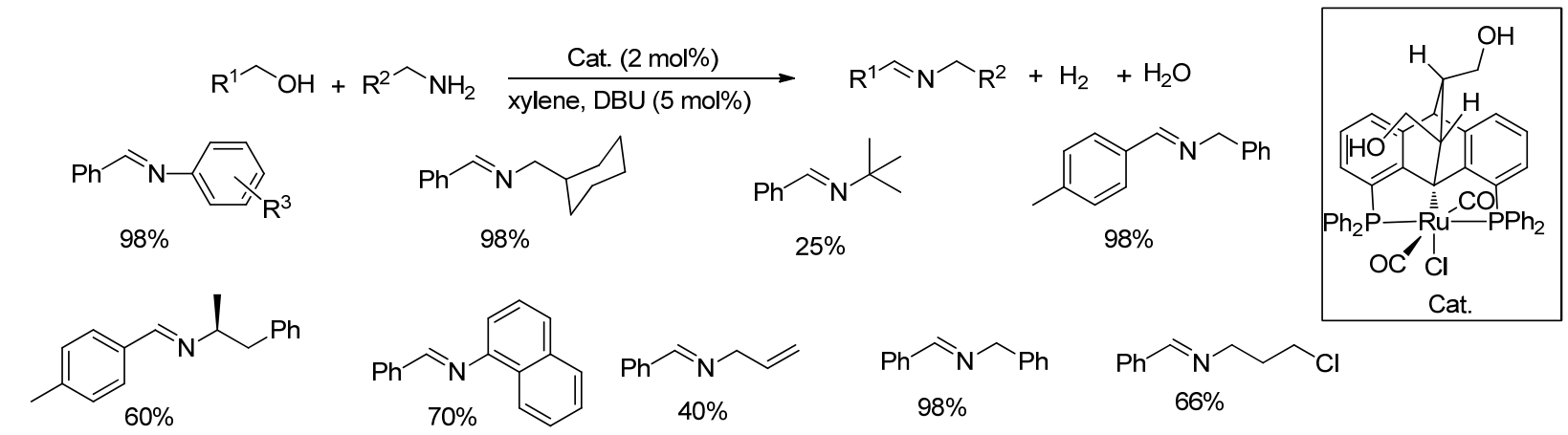

图式 31 新型钉配合物催化醇与胺无受体脱氢偶联生成亚胺的反应

Scheme 31 Direct coupling of alcohols and amines catalyzed by ruthenium complex

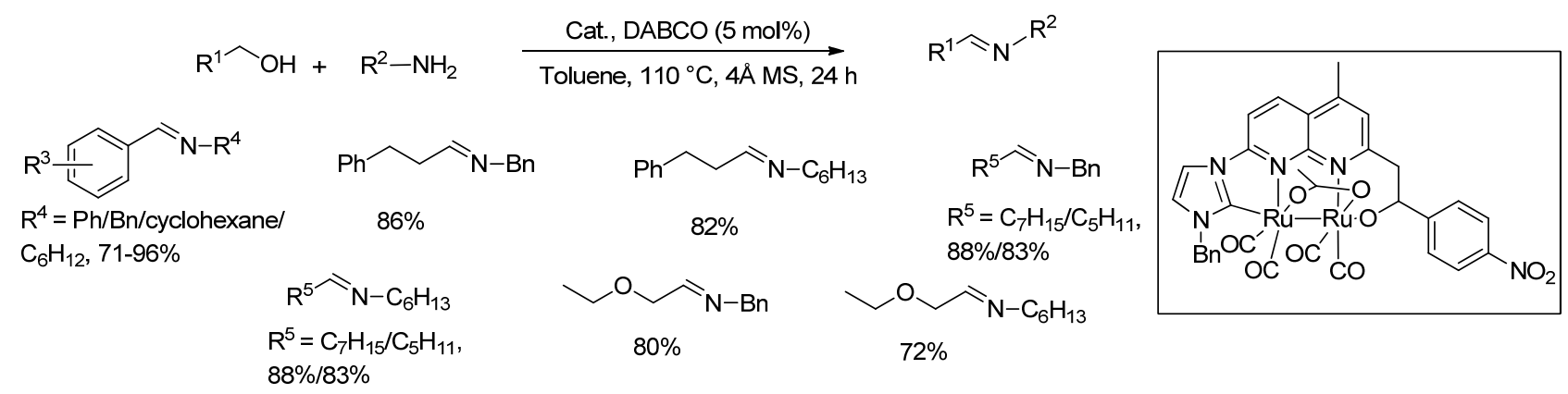

图式 32 新型的二钉配合物催化醇与胺偶联生成亚胺的反应

Scheme 32 Direct coupling of alcohols and amines catalyzed by double ruthenium complex

与不同胺的反应, 目标亚胺产物的收率也较高. 机理研 究表明, 该反应经历了一个醇脱氢生成醛, 随后醛与胺 迅速形成亚胺的过程, 但是该催化剂只有在碱性条件下 才有较好的催化醇脱氢的能力.

同年, Guan 等 ${ }^{[55]}$ 将 Saito 课题组开发的 Ru-Macho 催化剂(用于催化氢化还原酯为醇)转化为可用于脱氢的 预催化剂，并将该预催化剂用于伯醇和胺脱氢制备酰胺 的反应中，该预催化剂在碱存在下转化为具有催化活性 的 Ru-Macho 催化剂, 当底物醇为仲醇时, 则生成了亚 胺类产物，该催化剂对于催化醇和胺脱氢制备酰胺具有 重要的意义(Scheme 33).

2017 年, Mashima 等 ${ }^{[56]}$ 将 $\mathrm{RuCl}_{2}(\text { dppea })_{2}$ 与 $\mathrm{Zn}\left(\mathrm{OCOCF}_{3}\right)_{2}$ 和叔丁醇钾组成复合催化体系, 研究了其 催化醇和胺脱氢偶联制备亚胺的性能(Scheme 34). 以 $0.5 \mathrm{~mol} \%$ 钓配合物、 $1 \mathrm{~mol} \% \mathrm{Zn}\left(\mathrm{OCOCF}_{3}\right)_{2}$ 和 $20 \mathrm{~mol} \%$ 的 叔丁醇钾为催化剂, 醇和胺类底物在二氧六环中回流反 应 $18 \mathrm{~h}$, 目标亚胺的收率在 $25 \% \sim 83 \%$ 之间. 对于芐醇 类底物与正己胺的反应，收率在 $43 \% \sim 95 \%$ 之间，而正 己胺与苯丙醇反应的收率为 $76 \%$, 说明芳环上取代基的 类型和位置对收率影响较大. 此外, 对催化剂进行结构 变换得到的新钓配合物 $\left(\left[\mathrm{Ru}\left(\mathrm{OCOCF}_{3}\right)_{2}\{(S)-\mathrm{dppmp}\}_{2}\right]\right)$, 可用于催化醇和胺直接偶联制备酰胺的反应, 这一发现 对于催化醇和胺制备酰胺同样具有十分重要的意义.

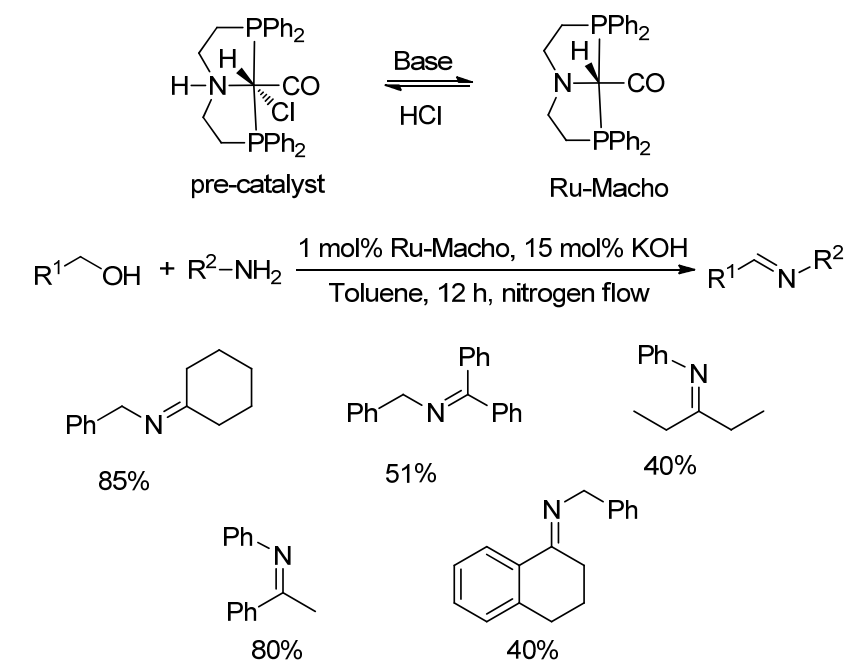

图式 $33 \mathrm{Ru}$-Macho 催化醇与胺偶联生成亚胺的反应 Scheme 33 Direct coupling of alcohols and amines catalyzed by Ru-Macho

2018 年, $\mathrm{Li}$ 等 ${ }^{[57]}$ 开发了氮膦功能化卡宾配体, 并将 其和 $\mathrm{Ru}(\mathrm{CON}) \mathrm{Cl}_{2}$ 组成催化体系用于催化醇烷基化胺的 反应. 发现在该催化体系中, 所得产物是亚胺和胺的混 合物, 且配体的类型和反应时间对产物(亚胺和胺)的比 例有重要影响. 


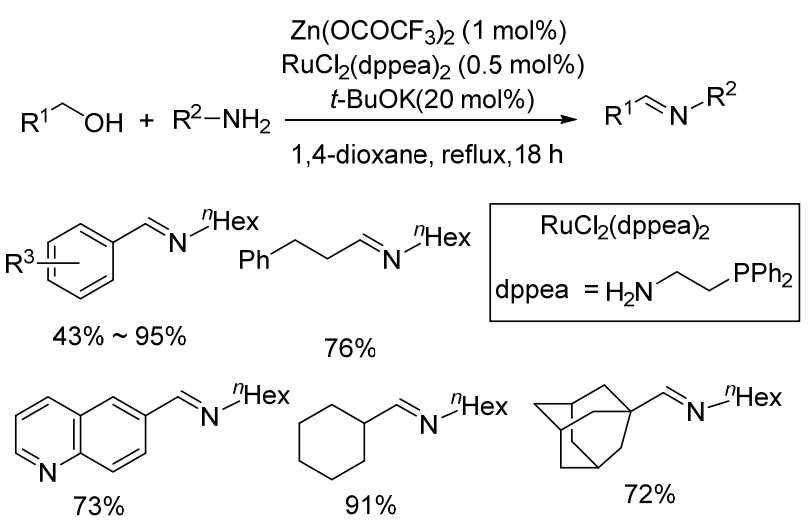

图式 34 钓配合物 $\left[\mathrm{Ru}\left(\mathrm{OCOCF}_{3}\right)_{2}\{(S) \text {-dppea }\}_{2}\right]$ 催化醇与胺偶 联生成亚胺的反应

Scheme 34 Direct coupling of alcohols and amines catalyzed by $\left[\mathrm{Ru}\left(\mathrm{OCOCF}_{3}\right)_{2}\{(S) \text {-dppea }\}_{2}\right]$

\section{4 铂类催化剂}

2011 年, Shiraishi 等 ${ }^{[58]}$ 将 $\mathrm{Pt}$ 纳米颗粒负载在二氧化 钛 $\left(\mathrm{TiO}_{2}\right)$ 上制备了一种 $\mathrm{Pt} @ \mathrm{TiO}_{2}$ 催化剂, 并研究了其在 紫外光条件下催化醇和芳胺偶联制备亚胺的性能. 在紫 外光照射 $(\lambda>300 \mathrm{~nm})$ 和氮气氛围下, 过量的醇和 50 $\mu \mathrm{mol}$ 胺在 $5 \mathrm{mg}$ 催化剂作用下室温反应, 亚胺的收率为 74\% 97\% (Scheme 35). 芐醇与甲基苯氨反应时, 亚胺 的收率为 $2-\mathrm{Me}>3-\mathrm{Me}>4-\mathrm{Me}$; 环已醇与苯胺反应的收 率为 $84 \%$. 该反应在室温进行, 除紫外光外无需其它添 加剂, 无其它副产物生成. 该催化方法虽然底物类型研 究相对较少, 但收率较好且较为绿色, 值得进一步研究.

$$
\begin{aligned}
& \mathrm{R}^{1} \widehat{\mathrm{OH}}+\mathrm{R}^{2}-\mathrm{NH}_{2} \frac{\left(\mathrm{Pt} @ \mathrm{TiO}_{2}\right) \text { catalyst }}{\mathrm{hv}(\lambda>300 \mathrm{~nm}) \text {, nitrogen, } 298} \mathrm{~K} \mathrm{R}^{1} \widehat{N}^{-}-\mathrm{R}^{2} \\
& \widehat{N}^{-P h} \\
& 80 \% \\
& \overbrace{86 \%}^{N^{-P h}} \\
& \overbrace{84 \%}^{N^{-P h}} \\
& \mathrm{Ph}_{\mathrm{N}} \mathrm{R}^{3} \\
& \mathrm{R}^{3}=2-\mathrm{Me} / 3-\mathrm{Me} / 4-\mathrm{Me} / 4-\mathrm{OMe} / 4-\mathrm{Cl} \text {, } \\
& 97 \% / 91 \% / 86 \% / 83 \% / 74 \%
\end{aligned}
$$

图式 $35 \mathrm{Pt} @ \mathrm{TiO}_{2}$ 催化醇与胺偶联生成亚胺的反应 Scheme 35 Direct coupling of alcohols and amines catalyzed by $\mathrm{Pt} @ \mathrm{TiO}_{2}$

\section{5 铜类催化剂}

2012 年, Ramón 等 ${ }^{[59]}$ 将氧化亚铜浸渍在在磁铁矿上 制备了一种 $\mathrm{CuO}-\mathrm{Fe}_{3} \mathrm{O}_{4}$ 催化剂, 并研究了其催化醇和芳 胺类底物直接脱氢偶联制备亚胺的性能. 在 $1.3 \mathrm{~mol} \%$ 催 化剂和 $140 \mathrm{~mol} \%$ 氢氧化钠存在下, 茮醇和芳胺类底物 在甲苯中 $100{ }^{\circ} \mathrm{C}$ 反应 $4 \mathrm{~d}$, 亚胺产物的收率为 $0 \% \sim 99 \%$ (Scheme 36). 大部分芐醇类与芳胺类底物的反应收率 都较高 $(62 \% \sim 99 \%), 3$-氯苯胺与苄醇的反应收率较低只
有 30\% , 位阻较大的 2,5-二甲基苯胺和芐醇反应收率也 只有 $41 \%$; 异丙醇与苯胺在该反应条件下无目标产物生 成; 当苄醇芳环上为单甲基取代时，亚胺的收率为间位 $>$ 对位; 而取代基为甲氧基则恰好相反. 当芳香醇和芳 香胺上的取代基都为 $\mathrm{Cl}$ 时，亚胺的收率为 $98 \%$. 该催化 剂廉价且易制备, 利用载体磁性回收容易，但是该催化 反应所需的时间较长且反应体系里需要加入过量的碱.

$$
\begin{aligned}
& \mathrm{R}^{1} \widehat{\mathrm{OH}}+\mathrm{R}^{2}-\mathrm{NH}_{2} \frac{\mathrm{CuO}-\mathrm{Fe}_{3} \mathrm{O}_{4}(1.3 \mathrm{~mol} \%)}{\mathrm{NaOH}\left(\begin{array}{c}
140 \mathrm{~mol} \%), \text { toluene } \\
100{ }^{\circ} \mathrm{C}, 4 \mathrm{~d}
\end{array}\right.} \mathrm{R}^{1} \widehat{\mathrm{N}}^{-} \mathrm{R}^{2} \\
& \mathrm{~N}_{\mathrm{N}} \mathrm{R}^{3} \\
& \mathrm{R}^{3}=\mathrm{H} / 3-\mathrm{Cl} / 4-\mathrm{OMe} / 2,5-\mathrm{Me}_{2}, \\
& 98 \% / 71 \% / 73 \% / 41 \% \\
& \mathrm{R}^{4}=4-\mathrm{Cl} / 4-\mathrm{Me} / 4-\mathrm{OMe} / 3-\mathrm{Me} / 3- \\
& \mathrm{OMe} / 3,5-\mathrm{Me}_{2} / 3,5-(\mathrm{OMe})_{2}, 80 \% / \\
& 69 \% / 97 \% / 99 \% / 62 \% / 74 \% / 93 \% \\
& \mathrm{Ph}_{\mathrm{N}^{-}} \mathrm{R}^{5}
\end{aligned}
$$

$\mathrm{R}^{5}={ }^{n} \mathrm{Bu} /{ }^{\mathrm{t}} \mathrm{BuCH} \mathrm{H}_{2} / \mathrm{Me}\left(\mathrm{CH}_{2}\right)_{11}, \mathrm{R}^{6}=4-\mathrm{Cl} / 4-\mathrm{OMe} / 3,5-\mathrm{Me}_{2} / 3,5-(\mathrm{OMe})_{2}$, $75 \% / 45 \% / 77 \%$ $98 \% / 30 \% / 86 \% / 89 \%$<smiles>CCCCN=Cc1ccccc1</smiles>

图式 $36 \mathrm{CuO}-\mathrm{Fe}_{3} \mathrm{O}_{4}$ 催化醇与胺偶联生成亚胺的反应 Scheme 36 Direct coupling of alcohols and amines catalyzed by $\mathrm{CuO}-\mathrm{Fe}_{3} \mathrm{O}_{4}$

\section{6 钯类催化剂}

2012 年, Wang 等 ${ }^{[60]}$ 以芐醇和苯胺为模型反应, 研 究了 $\mathrm{Pd} / \mathrm{DNA} 、 \mathrm{Au} / \mathrm{DNA} 、 \mathrm{Pt} / \mathrm{DNA} 、 \mathrm{Ag} / \mathrm{DNA} 、 \mathrm{Pd} / \mathrm{PVP}$ 、 $\mathrm{Pd} /$ starch $、 \mathrm{Pd} /$ Arabic gum、Pd/diatomite、Pd/MMT、Pd/C、 $\mathrm{PdCl}_{2}$ 等催化剂催化的直接亚胺化反应, 发现相同条件 下 $\mathrm{Pd} / \mathrm{DNA}$ 的催化效果最好. 该方法以 1.5 equiv.氢氧化 锂为碱、 $\mathrm{Pd} / \mathrm{DNA}$ ( $2.9 \mathrm{~mol} \%$ 钯)为催化剂, 水为溶剂在 $50{ }^{\circ} \mathrm{C}$ 下反应, 以 $96 \%$ 的产率得到目标产物亚胺 (Scheme 37). 底物拓展发现茮醇类底物中芳环取代基的类型和 位置对收率有较大影响, 当底物为 2 -取代的苄醇或 1-萗 甲醇时, 目标产物亚胺的收率均较低. 当苄醇上的取代 基为强供电子基团, 如甲基、甲氧基时, 产物亚胺的收 率与芳环上取代基位置之间总体呈现如下规律: 对位> 间位>邻位. 初步的机理研究(Scheme 38)表明, 该反应 为一串联反应, 醇先在催化剂作用下脱氢生成醛, 随后 醛和胺反应生成亚胺. 该催化剂循环使用 5 次而保持催 化活性. 该方法以水为溶剂, 条件较温和, 底物适用范 围较广, 催化剂回收容易且能循环使用, 该催化方法唯 一的不足是需要添加过量的碱氢氧化锂. 


$$
\text { R } \mathrm{R}^{1} \mathrm{OH}+\mathrm{R}^{2}-\mathrm{NH}_{2}
$$

$\mathrm{R}^{3}=\mathrm{H}, \mathrm{R}^{4}=\mathrm{Ph}, 96 \%$

$\mathrm{R}^{3}=\mathrm{H}, \mathrm{R}^{4}=4-\mathrm{MeOC}_{6} \mathrm{H}_{4}, 93 \%$

$\mathrm{R}^{3}=\mathrm{H}, \mathrm{R}^{4}=4-\mathrm{CF}_{3} \mathrm{C}_{6} \mathrm{H}_{4}, 72 \%$

$\mathrm{R}^{3}=\mathrm{H}, \mathrm{R}^{4}=n$-butyl, $89 \%$

$\mathrm{R}^{3}=\mathrm{H}, \mathrm{R}^{4}=3-\mathrm{MeC}_{6} \mathrm{H}_{4}, 93 \%$

$\mathrm{R}^{3}=\mathrm{H}, \mathrm{R}^{4}=2-\mathrm{MeC}_{6} \mathrm{H}_{4}, 69 \%$

$\mathrm{R}^{3}=\mathrm{H}, \mathrm{R}^{4}=4-\mathrm{FC}_{6} \mathrm{H}_{4}, 95 \%$

$\mathrm{R}^{3}=\mathrm{H}, \mathrm{R}^{4}=4-\mathrm{MeC}_{6} \mathrm{H}_{4}, 90 \%$

$\mathrm{R}^{3}=\mathrm{H}, \mathrm{R}^{4}=4-n-\mathrm{Bu}, 90 \%$

$\mathrm{R}^{3}=\mathrm{H}, \mathrm{R}^{4}=1-$ Naphthyl

$\mathrm{R}^{3}=\mathrm{H}, \mathrm{R}^{4}=t$-butyl, $95 \%$

$\mathrm{R}^{3}=\mathrm{H}, \mathrm{R}^{4}=4-\mathrm{MeOC}_{6} \mathrm{H}_{4}, 98 \%$

$\mathrm{R}^{3}=\mathrm{H}, \mathrm{R}^{4}=\mathrm{PhCH}_{2} \mathrm{CH}_{2}, 91 \%$

$\mathrm{R}^{3}=\mathrm{H}, \mathrm{R}^{4}=n-\mathrm{C}_{12} \mathrm{H}_{25}, 69 \%$

图式 $37 \mathrm{Pd} / \mathrm{DNA}$ 催化醇和胺的直接亚胺化反应

Scheme 37 Direct coupling of alcohols and amines catalyzed by Pd/DNA

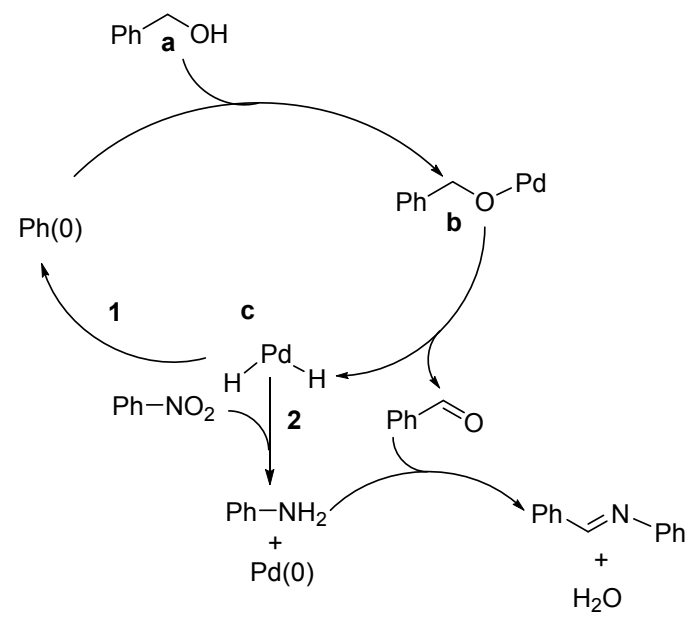

图式 38 钯纳米粒子 $(\mathrm{Pd} / \mathrm{DNA})$ 催化醇和胺合成亚胺的反应机 理

Scheme 38 Proposed mechanism for the catalytic oxidative synthesis of imines catalyzed by Pd/DNA

\section{7 钛类催化剂}

2014 年, Yang 和 $\mathrm{Xu}$ 等 ${ }^{[61]}$ 将二氧化钛 $\left(\mathrm{TiO}_{2}\right)$ 负载在 有机硅上制备了二氧化钛 $\mathrm{TiO}_{2} @$ PMHSIPN 催化剂, 并 将其用于催化醇与苯胺类底物直接脱氢偶联制备亚胺 的反应. 在无溶剂、 $2 \mathrm{~mol} \%$ 催化剂、 $20 \mathrm{~mol} \%$ 碳酸钾和 氩气氛围下, 茮醇类和芳胺类底物在 $160{ }^{\circ} \mathrm{C}$ 反应 $12 \mathrm{~h}$,
亚胺的收率为 59\%～99\% (Scheme 39). 对于茮醇与苯 胺类底物的反应，无论芳环连有吸电子或供电子取代 基，都能以优异的收率得到目标亚胺; 对于 4-甲基苯胺 与苄醇类底物的反应，除 2,6-二氯苄醇与 4-甲基苯胺的 收率较低外 $(59 \%)$, 也都能以优异的产率得到目标产物, 而且芳环上取代基位置对亚胺收率几乎没有影响. 该催 化剂以环境友好的有机硅材料和商业上可用的钛前驱 体为原料，避免了过渡金属的使用. 该反应体系不需要 使用氧化剂或其它添加剂, 且副产物仅为水或氢气，但 该反应温度太高且反应体系中需要碳酸钾的参与.

$$
\begin{aligned}
& \mathrm{TiO}_{2} @ P M H S I P N(2 \text { mol\% Ti) } \\
& \mathrm{R}^{1} \Upsilon_{\mathrm{OH}}+\mathrm{R}^{2}-\mathrm{NH}_{2} \frac{\mathrm{K}_{2} \mathrm{CO}_{3}(20 \mathrm{~mol} \%)}{\text { solvent-free, } 160{ }^{\circ} \mathrm{C}, 12 \mathrm{~h}} \mathrm{R}^{1} \overbrace{\mathrm{N}^{-}} \mathrm{R}^{2} \\
& \overbrace{\mathrm{Nh}} \mathrm{R}^{3}
\end{aligned}
$$

$\mathrm{R}^{3}=\mathrm{H} / 2-\mathrm{Me} / 3-\mathrm{Me} / 4-\mathrm{Me} / 2-\mathrm{OMe} / 3-\mathrm{Br} / 4-\mathrm{Br} / 4-\mathrm{NO}_{2} / 2-\mathrm{Cl} /$ 3-Cl/4-Cl/2-OEt/4-OEt/2,4-(OMe) $)_{2}, 94 \% / 99 \% / 99 \% 99 \% /$ 99\%/99\%/99\%/88\%/99\%/92\%/92\%/99\%/99\%/94\%<smiles>[R1]c1ccc(/C=N/c2ccc(C)cc2)cc1</smiles>

$\mathrm{R}^{4}=2-\mathrm{Br} / 4-\mathrm{Br} / 2-\mathrm{F} / 2-\mathrm{Me} / 4-\mathrm{Me} / 4-\mathrm{Cl} / 2-\mathrm{OMe} / 3-\mathrm{OMe} / 4-$ $\mathrm{OMe} / 2,4-\mathrm{Cl}_{2} / 2,6-\mathrm{Cl}_{2}, 96 \% / 93 \% / 99 \% / 99 \% / 99 \% / 84 \% /$ $99 \% / 99 \% / 98 \% / 99 \% / 59 \%$

图式 $39 \mathrm{TiO}_{2} @$ PMHSIPN 催化剂催化醇与胺偶联生成亚胺的 反应

Scheme 39 Coupling reaction of alcohol and amine to produce imines catalyzed by $\mathrm{TiO}_{2} @$ PMHSIPN

\section{8 铁类催化剂}

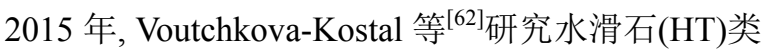
非均相催化剂时, 发现 Fe:Mg:Al HT (HT4)能催化醇类 物质的脱氢反应以及醇和胺的亚胺化反应, 该催化体系 催化 4-甲氧基苄醇和 4-甲氧基苯胺反应的收率达到了 97\% (Scheme 40). 底物拓展研究发现, 对于苠醇类底物 与芳胺类底物的反应，收率在 $15 \% \sim 97 \%$ 之间. 而环辛 醇、正辛醇与 4-甲氧基苯胺在该条件下不发生反应. 作 者研究的底物类型较少, 且从有限的反应结果来看, 该 催化剂活性较低、底物适用范围有限且总体收率均不高.

2016 年, Balaraman 等 ${ }^{[63]}$ 制备了Fe-Phen@C 催化剂, 并将该非均相催化剂用于催化醇与胺的无受体脱氢直 接偶联生成亚胺的反应. 在 $8 \mathrm{~mol} \%$ 催化剂、 $10 \mathrm{~mol} \%$ $t$-BuOK 和氩气存在下, 醇和胺在正辛烷中 $120{ }^{\circ} \mathrm{C}$ 反应 $24 \mathrm{~h}$, 目标亚胺的收率良好(Scheme 41). 对底物研究发 现，对氯茮醇与不同取代基的苯胺反应时，当苯胺 3,4 位连有二个甲氧基时，亚胺的收率较低只有 $51 \%$. 对苯 
<smiles>[R]C=NC[R]</smiles>

图式 40 水滑石(HT4)类非均相催化剂催化醇和胺的亚胺化反应

Scheme 40 Direct coupling of alcohols and amines catalyzed by hydroimide (HT4)

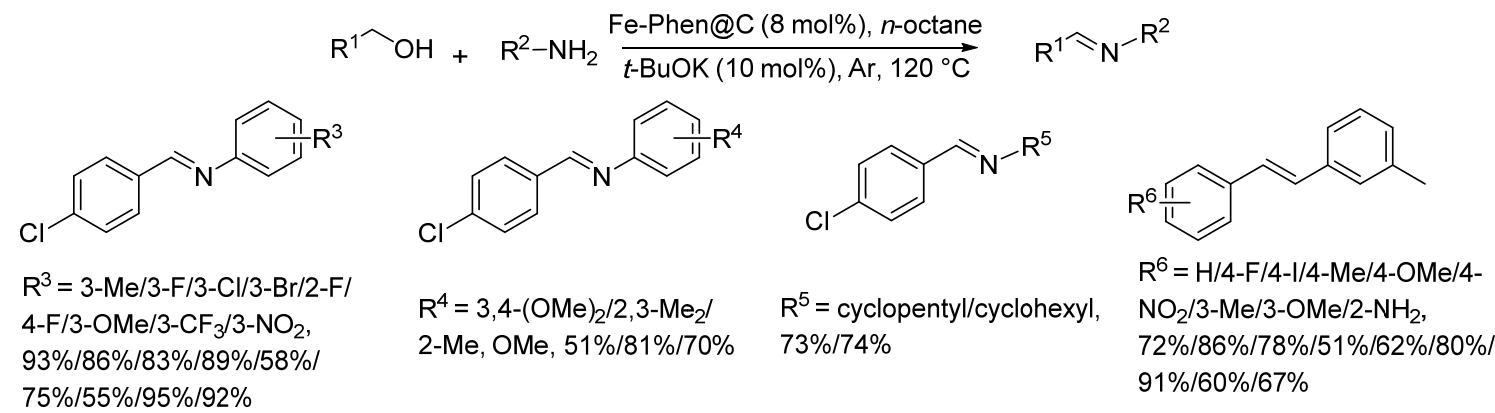<smiles>Clc1ccc(/C=N/C2CCCC3C=CC=CC32)cc1</smiles><smiles>Clc1ccc(/C=N/c2cccc3ccccc23)cc1</smiles><smiles>Cc1cccc(/N=C/c2ccco2)c1</smiles><smiles>COc1cc(Br)ccc1/C=C/c1cccc(C)c1</smiles><smiles>Cc1cccc(/N=C/C=C/c2ccccc2)c1</smiles><smiles>Clc1ccc(/C=N/c2cccc(/N=C/c3ccc(Cl)cc3)c2)cc1</smiles><smiles>Clc1ccc(/C=N/C(c2ccccc2)c2ccccc2)cc1</smiles>

$62 \%$<smiles>Clc1ccc(/C=N/Cc2ccccc2)cc1</smiles>

$40 \%$

图式 41 Fe-Phen@C 催化醇和胺制备亚胺的反应

Scheme 41 Direct coupling of alcohols and amines catalyzed by Fe-Phen@C

胺上取代基的位置研究发现, 亚胺的产率为: 间位 $>$ 对 位>邻位. 该催化剂对对氯茮醇与正已胺以及已醇与 3甲基苯胺的反应几乎没有效果, 均以痕量收率得到目标 产物. 该催化剂回收容易可以循环使用六次, 可以放大 到克级以上的规模. 该催化方法的副产物只有氢气和 水, 对环境没有污染, 符合绿色化学的发展理念, 唯一 不足是反应体系中需要加入强碱叔丁醇钾.

\section{9 锰类催化剂}

2016 年, Milstein 等 ${ }^{[64]}$ 制备了 Mn-PNP 双齿配合物 催化剂, 首次将其用于催化醇与胺脱氢偶联制备亚胺的 反应(Scheme 42). 该方法以苯为溶剂, 氮气氛围下将物 质的量比为 $1: 1$ 的底物醇和胺在 $135{ }^{\circ} \mathrm{C}$ 反应 $60 \mathrm{~h}$, 以 42\% 99\%的收率生成目标产物亚胺. 其可能的催化机 理如 Scheme 43 所示.

同年, Kirchner 等 ${ }^{\left[{ }^{65]}\right.}$ 也报道了 MnI-PNP 双齿配合物 催化醇与胺脱氢偶联制备亚胺的反应. 以甲苯替代上述 方法的苯为溶剂, 且在反应体系中加入分子篮以去除反 应产生的水, 以 $3 \mathrm{~mol} \% \mathrm{MnI}-\mathrm{PNP}$ 为催化剂, 将茮醇和 芳胺在 $140{ }^{\circ} \mathrm{C}$ 下反应 $16 \mathrm{~h}$, 所得亚胺产物的产率为

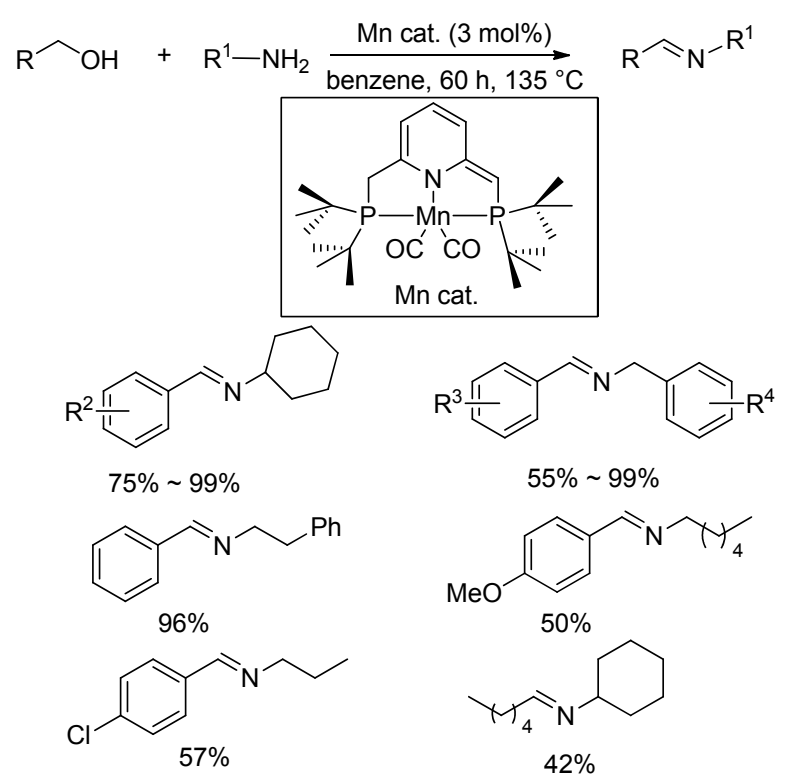

图式 42 双齿配合物催化剂 Mn-PNP 催化醇和胺制备亚胺的 反应

Scheme 42 Direct coupling of alcohols and amines catalyzed by Mn-PNP 


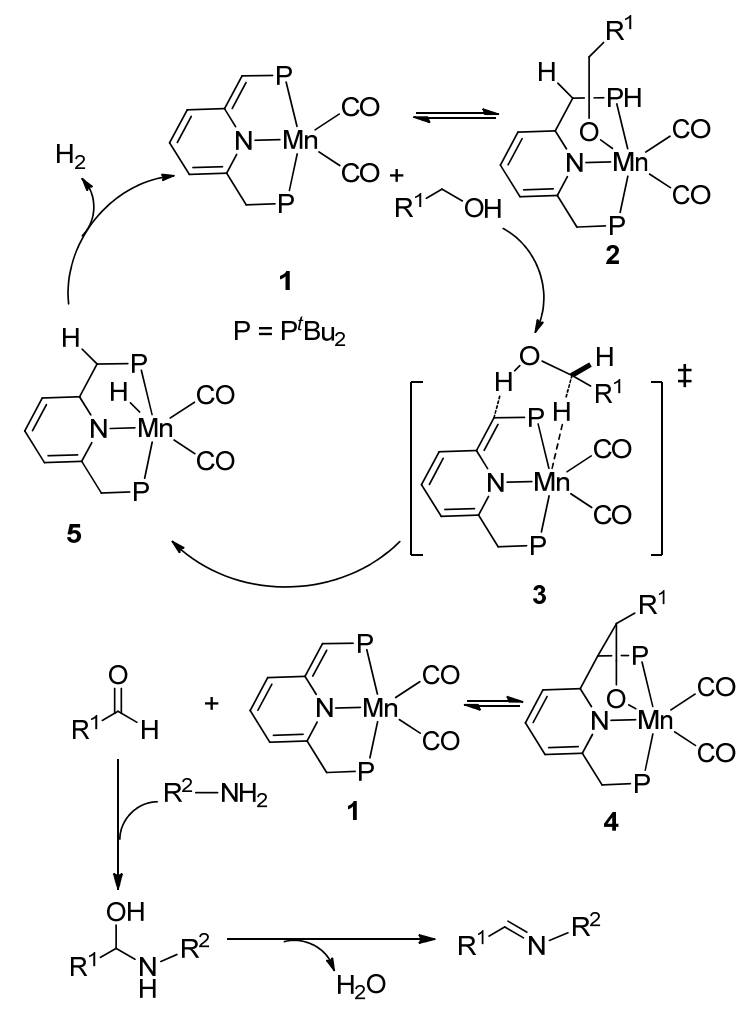

图式 43 双齿配合物催化剂 Mn-PNP 催化醇和胺制备亚胺的 反应机理

Scheme 43 Proposed mechanism of preparation of imines from alcohols and amines catalyzed by Mn-PNP complex

$60 \% \sim 92 \%$. 当醇为正丁醇时, 亚胺的收率只有 $17 \%$, 该催化体系可能不适合长链的醇类底物. 该反应体系无 需氧化剂参与, 所采用的金属廉价易得, 催化剂易制备 且具有绿色环保等特点, 但催化剂的回收和循环使用不 易.
2018 年, Kempe 等 ${ }^{[66}$ 将 $\mathrm{PN}_{5} \mathrm{P}$ 型锰催化剂用于催化 醇和胺的偶联反应, 并惊奇地发现, 醇和胺的偶联产物 类型取决于反应体系中的碱. 当采用叔丁醇钾为碱时, 得到的产物为胺; 而采用叔丁醇钠为碱时, 则得到亚胺 (Scheme 44). 对于茮醇类底物与苯胺的反应，在催化剂 和叔丁醇钠作用下，亚胺的收率在 $75 \%$ $91 \%$ 之间，长 链的醇与苯胺则无亚胺产物生成; 对于苠醇类和芳胺类 底物的反应，亚胺的收率在 52\% 93\%之间；4-苯基丁 胺与苄醇反应的收率只为 $55 \%$. 该方法催化剂用量少且 适用于碱性较弱的芳胺类底物与醇的反应. 锰作为廉价 金属，展现了替代贵重金属铱和钉的巨大潜力.

\subsection{0 锇类催化剂}

2011 年, Honczek 等 ${ }^{[67]}$ 制备了一种磷氧磷(POP)型 锇复合物, 并研究了其在醇胺无受体脱氢制备亚胺反应 中的催化活性. 在 $0.2 \mathrm{~mol} \%$ 的催化剂和 $10 \mathrm{~mol} \%$ 的氢氧 化钾存在条件下，醇和胺类底物在 $150{ }^{\circ} \mathrm{C}$ 的甲苯中带 压反应 3 $24 \mathrm{~h}$ ，收率在 30\% 98\%之间. 对于茮醇和苯 胺类底物的反应，收率在 $87 \% \sim 98 \%$ 之间(Scheme 45). 对于链状脂肪醇和脂肪胺或环己胺的反应, 收率在 80\% 94\%之间; 环已基甲醇与正庚胺反应的收率仅为 $37 \%$, 环己醇与正庚胺的收率在 $30 \%$. 该催化方法反应 温度较高, 有一定的底物适用范围, 但总体收率不高. 由于作者对每一类底物的类型研究较少, 所以底物结构 类型对收率的影响规律尚不易得出. 然而, 金属锇是非 常有希望作为金属钉的替代物应用于催化醇胺偶联制 备亚胺的反应. 催化机理如 Scheme 46 所示.<smiles>[R]1ccc(/C=N/c2ccccc2)cc1</smiles>

$\mathrm{R}^{3}=\mathrm{H} / 4-\mathrm{Cl} / 4-\mathrm{Br} / 4^{t} \mathrm{Bu} / 4-\mathrm{OMe} / 3-\mathrm{Me} / 2-\mathrm{Me}, \quad 78 \%$ $84 \% / 90 \% / 75 \% / 86 \% / 80 \% / 87 \% / 88 \%$<smiles>C(=N\c1ccccc1)\c1cccc2ccccc12</smiles>

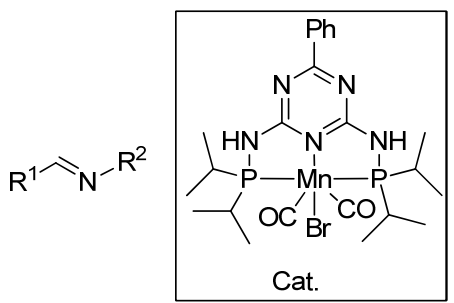<smiles>C(=N/c1cccs1)\c1cccs1</smiles>
$91 \%$<smiles>[R]1ccc(/N=C/c2ccccc2)cc1</smiles><smiles>C(=N/c1ccc(-c2ccccc2)cc1)\c1cccs1</smiles>

$\mathrm{R}^{4}=4-\mathrm{Cl} / 4-\mathrm{Br} / 4-\mathrm{I} / 4-\mathrm{Et} / 2-$ tert $-\mathrm{Butyl} / \quad 91 \%$ 2-Phenyl/3,5-Dimethyl, 64\%/73\%/ $62 \% / 83 \% / 77 \% / 66 \% / 93 \%$<smiles>CC(C)(C)c1ccc(/C=N/c2ccc(Cl)cc2)cc1</smiles><smiles>Clc1ccc(/N=C/c2ccc(I)cc2)cc1</smiles>

$52 \%$

图式 $44 \mathrm{Mn}$ 催化剂催化醇与胺偶联生成亚胺的合成的反应

Scheme 44 Direct coupling of alcohols and amines catalyzed by Mn complex 


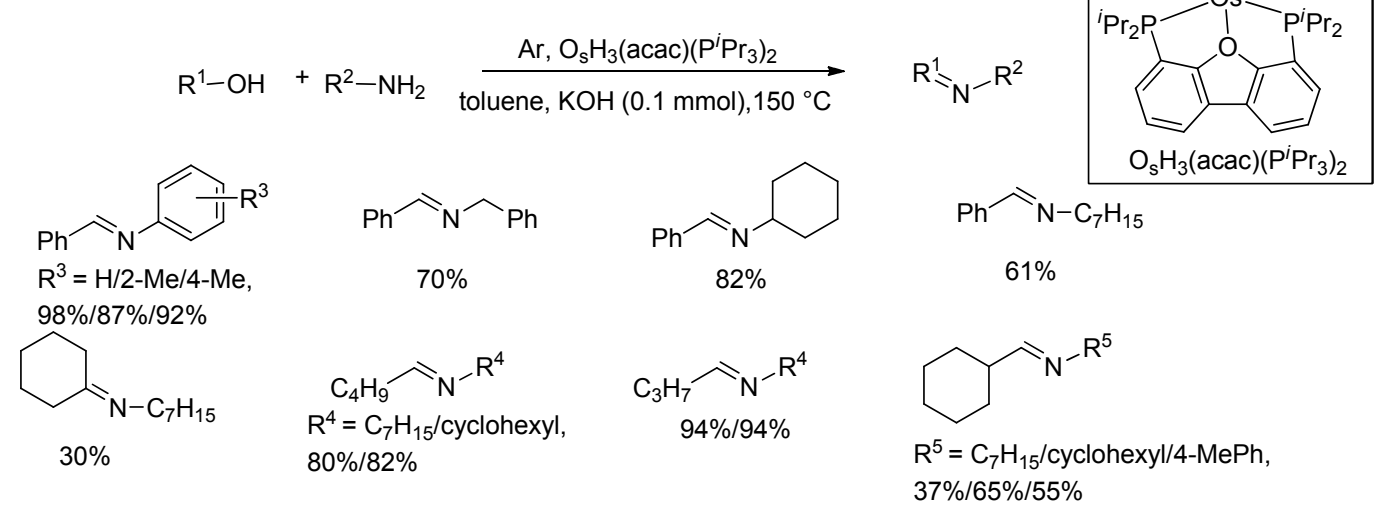

图式 $45 \mathrm{O}_{\mathrm{s}} \mathrm{H}_{3}(\mathrm{acac})\left(\mathrm{P}^{i} \mathrm{Pr}_{3}\right)_{2}$ 催化醇与胺偶联生成亚胺的合成的反应

Scheme 45 Direct coupling of alcohols and amines catalyzed by $\mathrm{O}_{\mathrm{s}} \mathrm{H}_{3}(\mathrm{acac})\left(\mathrm{P}^{\mathrm{i}} \mathrm{Pr}_{3}\right)_{2}$

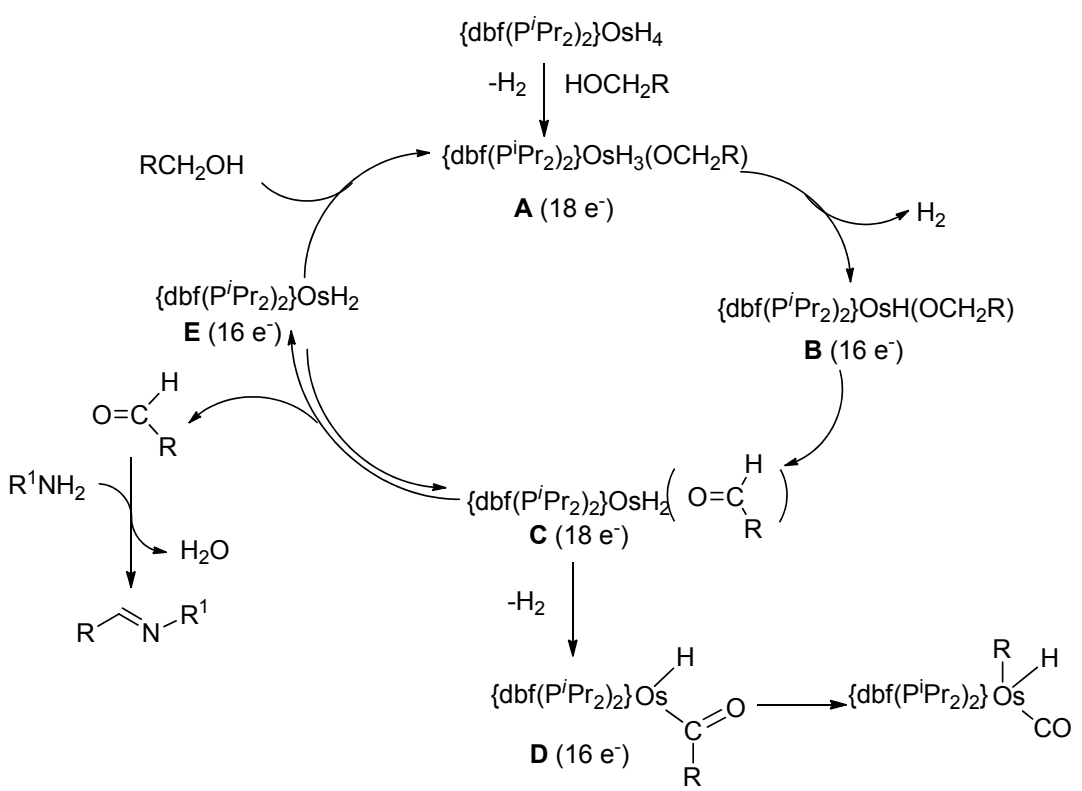

图式 46 三氢化物 $\mathrm{O}_{\mathrm{s}} \mathrm{H}_{3}(\mathrm{acac})\left(\mathrm{P}^{\mathrm{i}} \mathrm{Pr}_{3}\right)_{2}$ 催化的亚胺的合成的反应机理

Scheme 46 Proposed mechanism for the synthesis of imines catalyzed by $\mathrm{O}_{\mathrm{s}} \mathrm{H}_{3}(\mathrm{acac})\left(\mathrm{P}^{\mathrm{i}} \mathrm{Pr}_{3}\right)_{2}$

\subsection{1 钼类催化剂}

2018 年, Madsen 等 ${ }^{[68]}$ 开发了一种基于氮杂环卡宾、 dppe 和金属钼组成的催化体系, 并将其应用于催化醇 与胺脱氢偶联生成亚胺的反应. 在 $10 \mathrm{~mol} \% \mathrm{Mo}(\mathrm{Co})_{6}$ 、 $20 \mathrm{~mol} \%$ 的 1,3-双环已基咪唑氯化铵、 $10 \mathrm{~mol} \%$ dppe、20 $\mathrm{mol} \%$ 叔丁醇钾和分子篎存在下, 醇和胺在 $1,3,5$-三甲苯 中回流反应 $60 \mathrm{~h}$, 目标亚胺产物的收率在 15\% $89 \%$ 之 间(Scheme 47). 对于苠醇类底物和环己胺的反应来说, 亚胺的收率在 32\% $89 \%$ 之间, 芳环的 4 位上含有供电 子取代基时, 亚胺产物收率较高; 4-硝基苄醇与环己胺 的反应, 由于硝基发生竞争性还原使得其亚胺收率仅为 $58 \%$. 对碘茮醇则由于脱碘或亚胺还原等副反应的影 响, 亚胺产率只有 37\%. 1-或 2-菜基甲醇与环己胺反应 的收率分别为 $75 \%$ 和 $80 \%$. 不同的胺类底物与苯甲醇反
应时，对氯苄胺由于脱卤等反应的影响，产率仅为 $15 \%$. 空间位阻大的 1-金刚烷基胺与苄醇反应的亚胺收率为 $52 \%$. 该催化方法也适用于苯胺和对甲氧及苯胺与茮醇 的反应，产率分别为 73\%和 70\%. 该方法催化剂相对廉 价，底物适用范围较广. 催化体系虽然需要添加多种配 体和碱，但属首次使用钿类金属作为脱氢催化剂，具有 开创性.

\section{3 结束语}

从现有研究成果来看, 金属催化剂催化醇胺偶联制 备亚胺, 基本可以分为两类: 一类是在氧气或空气存在 下，选择性氧化醇为醛，随后酫与胺反应生成亚胺，其 中铜、锰、金三类金属的研究较为深入, 而金属钯和钉 


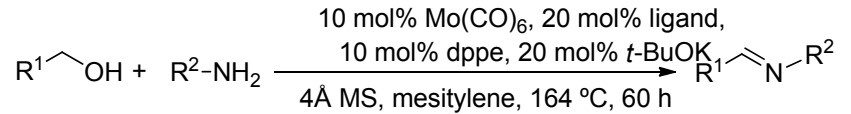<smiles>[R1]1ccc(/C=N/C2CCCCC2)cc1</smiles>

$\mathrm{R}^{3}=\mathrm{H} / 4-\mathrm{Me} / 4-\mathrm{OMe} / 4-\mathrm{MeS} / 4-\mathrm{Ph} / \mathrm{NO}_{2} /$ 4-F/4-Cl/4-Br/4-I/2-Me/2-OH, 89\%/80\%/<smiles>C(=N/C1CCCCC1)\c1cccc2ccccc12</smiles>

$75 \%$<smiles>C(=N/C(c1ccccc1)c1ccccc1)\c1ccccc1</smiles>

$45 \%$<smiles>[R]#CCc1ccc(CN=Cc2ccccc2)cc1</smiles>

$\mathrm{R}^{4}=\mathrm{H} / \mathrm{Cl}, 88 \% / 15 \%$<smiles>C(=Nc1ccccc1)c1ccccc1</smiles>

$\mathrm{R}^{5}=\mathrm{H} / \mathrm{OMe}, 73 \% / 70 \%$ $87 \% / 70 \% / 62 \% / 58 \% / 79 \% / 65 \% / 68 \% / 37 \% /$ $70 \% / 32 \%$

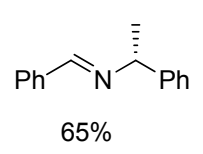

$65 \%$<smiles>CC(N=Cc1ccccc1)c1cccc2ccccc12</smiles>

$58 \%$

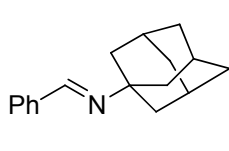

$52 \%$<smiles>C(=NC1CCCCC1)c1ccc2ccccc2c1</smiles>

$80 \%$

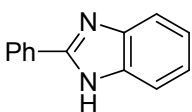

$65 \%$

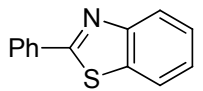

$54 \%$

图式 $47 \mathrm{Mo}(\mathrm{Co})_{6}$ 催化醇与胺偶联生成亚胺的合成的反应

Scheme 47 Direct coupling of alcohols and amines catalyzed by $\mathrm{Mo}(\mathrm{Co})_{6}$ and $\mathrm{NHC}$-ligand

催化的氧化偶联则具有非常重要的引领意义. 另外一类 是催化醇和胺脱氢偶联生成亚胺, 相比催化氧化偶联方 法, 这类方法更加绿色环保, 除贵金属钉研究较为深入 外, 其它如铱、铂、铜、钯、钛、锇、钿、钴、铁、锰 等金属的催化醇胺偶联脱氢也相继展开, 虽然不是很成 熟, 但都是开创性的工作, 且具有重要的引领作用. 金 属催化剂的发展为催化合成亚胺提供了新的途径, 虽然 已经获得了重要进展, 但是仍然存在不足. 催化醇胺氧 化偶联方面, 虽然所研究的金属类型已经较多, 但是大 都处于初期阶段, 大部分催化体系中仍然需要多种添加 物且其底物适用范围不明确; 催化醇胺脱氢偶联方面, 除均相钉类催化剂外，其它金属类型的研究虽较多但同 样处于初期阶段, 也存在催化体系需要多种添加物; 反 应温度高时间长, 催化剂回收困难, 底物适用范围有限; 产物收率不高且易生成亚胺被还原的副产物等不足. 因 此开发新型催化剂时, 应尽可能减少或避免催化体系中 的添加物, 在提高催化剂活性和选择性的同时, 还应考 虑催化剂的回收循环; 且更要注重廉价金属催化剂的开 发.

\section{References}

[1] Marques, C. S.; Burke, A. J. ChemInform 2011, 3, 635.

[2] Bayrak, H.; Demirbas, A.; Karaoglu, S. A.; Demirbas, N. Eur. J. Med. Chem. 2009, 44, 1057

[3] Gawronski, J.; Wascinska, N.; Gajewy, J. Chem. Rev. 2008, 108, 5227.

[4] Kobayashi, S.; Mori, Y.; Fossey, J. S.; Salter, M. M. Chem. Rev. 2011, 111, 2626.

[5] And, S. K.; Ishitani, H. Chem. Rev. 1999, 99, 1069

[6] Nielsen, M.; Worgull, D.; Zweifel, T.; Gschwend, B.; Bertelsen, S.; Jørgensen, K. A. Chem. Commun. 2011, 47, 632.

[7] Marques, C. S.; Burke, A. J. ChemCatChem 2011, 3, 635.

[8] Uematsu, N.; Fujii, A.; Hashiguchi, S.; Ikariya, T.; Noyori, R. J. Am. Chem. Soc. 1996, 118, 4916.

[9] Thalji, R. K.; Ahrendt, K. A.; Bergman, R. G.; Ellman, J. A. ChemInform 2010, 33, 9692.
[10] Nieto, S.; Dragna, J. M.; Anslyn, E. V. Chem.-Eur. J. 2010, 16, 227.

[11] Dhakshinamoorthy, A.; Alvaro, M.; Garcia, H. ChemCatChem 2010, 2, 1438.

[12] Nakajima, R.; Ogino, T.; Yokoshima, S.; Fukuyama, T. J. Am. Chem. Soc. 2010, 132, 1236.

[13] Hadjipavlou-Litina, D. J.; Geronikaki, A. A. Drug Des. Discovery $1998,15,199$.

[14] Akhmetova, V. R.; Khabibullina, G. R.; Rakhimova, E. B. Mol. Diversity 2010, 14, 463.

[15] Nielsen, M.; Worgull, D.; Zweifel, T.; Gschwend, B.; Bertelsen, Jørgensen, K. A. Chem. Commun. 2011, 47, 632.

[16] Kobayashi, S.; Mori, Y.; Fossey, J. S.; Salter, M. M. Chem. Rev. 2011, 111, 2626.

[17] Xie, J. H.; Zhu, S. F.; Zhou, Q. L. Chem. Rev. 2011, 111, 1713.

[18] Marques, C. S.; Burke, A. J. ChemCatChem. 2011, 3, 635.

[19] Nieto, S.; Dragna, J. M.; Anslyn, E. V. Chem.-Eur. J. 2010, 16, 227.

[20] Dhakshinamoorthy, A.; Alvaro, M. ChemCatChem 2010, 2, 1438.

[21] Aschwanden, L.; Mallat, T.; Maciejewski, M.; Krumeich, F.; Baiker, A. ChemCatChem 2010, 2, 666.

[22] Min, S. K.; Kim, S.; Park, S.; Park, S.; Bosco, W.; Chidrala, R. K.; Park, J. J. Org. Chem. 2009, 74, 2877.

[23] Jiang, L.; Jin, L. L.; Tian, H. W.; Yuan, X. Q.; Yu, X. C.; Xu, Q. Chem. Commun. 2011, 47, 10833.

[24] Chen, G. J.; Ma, H. C.; Xin, W. L.; Li, X. B.; Jin, F. Z.; Wang, J. S.; Liu, M. Y.; Dong, Y. B. Inorg. Chem. 2017, 56, 654.

[25] Tian, H. W.; Yu, X. C.; Li, Q.; Wang, J. X.; Xu, Q. Adv. Synth. Catal. 2012, 354, 2671.

[26] Kang, Q.; Zhang, Y. G. Green Chem. 2012, 43, 1016.

[27] Bai, L.; Dang, Z. RSC Adv. 2015, 5, 10341.

[28] Darapanani, C. M.; Arghya, S.; Galia, M. J. Catal. 2017, 355, 139.

[29] Wei, Y. G.; Yu, H.; Zhai, Y. Y.; Dai, G. Y.; Ru, S.; Han, S. Chem.Eur. J. 2017, 23, 13883.

[30] And, L. B.; Taylor R, J. K. Org. Lett. 2001, 4, 1637.

[31] Sithambaram, S.; Kumar, R.; Son, Y. C.; Steven, L. J. Catal. 2008, $253,269$.

[32] Mondal, J.; Borah, P.; Sreejith, S.; Nguyen, K. T.; Han, X. G.; Ma, X.; Zhao, Y. L. ChemCatChem 2014, 6, 3518.

[33] Chen, B.; Li, J.; Dai, W.; Wang, L. Y.; Gao, S. Green Chem. 2014, $16,3328$.

[34] Zhang, E, L.; Tian, H. W.; Xu, S. D.; Yu, X. C.; Xu, Q. Org. Lett. 2013, 15, 2704.

[35] Geng, L. L.; Song, J. L.; Zheng, B.; Wu, S. J.; Zhang, W. X.; Jia, M. J.; Liu, G. Chin. J. Catal. 2016, 37, 1451.

[36] Sindhuja, E.; Ramesh, R. Tetrahedron Lett. 2014, 55, 5504.

[37] Sun, H.; Su, F. Z.; Ni, J.; Cao, Y.; He, H. Y.; Fan, K. N. Angew. Chem., Int. Ed. 2009, 48, 4390. 
[38] Kegnæs, S.; Mielby, J.; Mentzel, U. V.; Christensen, C. H.; Riisager, A. Green Chem. 2010, 12, 1437.

[39] Liu, P.; Li, C.; Hensen, E. J. Chem.-Eur. J. 2012, 18, 12122.

[40] Soulé, J. F.; Miyamura, H.; Kobayashi, S. Chem. Commun. 2013, $49,355$.

[41] Huang, R.; Yang, Y.; Wang, D. S.; Zhang, L.; Wang, D. W. Org. Chem. Front. 2017, 5, 203.

[42] Han, L.; Xing, P.; Jiang, B. Org. Lett. 2014, 16, 3428.

[43] Mielby, J.; Poreddy, R.; Engelbrekt, C.; Kegnæs, S. Chin. J. Catal. 2014, 35, 670 .

[44] Zhang, G. Q.; Hanson, S. K. Org. Lett. 2013, 15, 650.

[45] Sun, Y. W.; Lu, X. H.; Wei, X. L.; Zhou, D.; Xia, Q. H. Catal. Commun. 2014, 43, 213.

[46] Midya, S. P.; Pitchaimani, J.; Landge, V. G.; Madhu, V.; Ekambaram, B. Catal. Sci. Technol. 2018, 8, 3469.

[47] Xu, C.; Lai, Goh, L. Y.; Pullarkat, S. A. Organometallics. 2011, 30, 6499.

[48] Chang, Y. H.; Tanigawa, I.; Takeuchi, K.; Taguchi, H.; Ozawa, F. Eur. J. Inorg. Chem. 2016, 5, 754.

[49] Gnanaprakasam, B.; Zhang, J.; Milstein, D. Angew. Chem., Int. Ed. 2010, 49, 1468

[50] Cano, R.; Ramón, D. J.; Yus, M. J. Org. Chem. 2011, 76, 5547.

[51] Maggi, A.; Madsen, R. Organometallics 2012, 31, 451.

[52] Jared, W. R.; Sara, A. M.; Simon, D. P.; Jennifer, M. S. Org. Biomol. Chem. 2012, 10, 1746.

[53] Musa, S.; Fronton, S.; Vaccaro, L.; Gelman, D. Organometallics 2013, 32, 3069.

[54] Saha, B.; Daw, P.; Sengupta, G.; Rahaman, S. M.; Bera, J. K. Chem.-Eur. J. 2014, 20, 6542.
[55] Oldenhuis, N. J.; Dong, V. M.; Guan. Z. B. Tetrahedron 2014, 70, 4213.

[56] Higuchi, T.; Tagawa, R.; Iimuro, A.; Akiyama, S.; Nagae, H.; Mashima, K. Chem.-Eur. J. 2017, 23, 12795.

[57] Yu, X. J.; Li, Y. Q.; Fu, H. Y.; Zheng, X. L.; Chen, H.; Li, R. X. Appl. Organomet. Chem. 2018, 32, 4277.

[58] Shiraishi, Y.; Ikeda, M.; Tsukamoto, D.; Tanaka, S.; Hirai, T. Chem. Commun. 2011, 47, 4811.

[59] Pérez, J. M.; Cano, R.; Yus, M.; Ramón, D. J. Eur. J. Org. Chem. 2012, 24, 4548 .

[60] Tang, L.; Sun, H. Y.; Li, Y. F.; Zha, Z. G.; Wang, Z. Y. Green Chem. 2012, 14, 3423.

[61] Wang, H.; Zhang, J.; Cui, Y. M.; Yang, K. F.; Zheng, Z. J.; Xu, L. W. RSC. Adv. 2014, 4, 34681.

[62] Bain, J.; Cho, P.; Voutchkova-Kostal, A. Green Chem. 2015, 17, 2271.

[63] Jaiswal, G.; Landge, V. G.; Jagadeesan, D.; Balaraman, E. Green Chem. 2016, 47, 3232.

[64] Mukherjee, A.; Nerush, A.; Leitus, G.; Shimon L, J. W.; David, Y. B.; Jalapa N, A. E.; Milstein, D. J. Am. Chem. Soc. 2016, 138 , 4298.

[65] Mastalir, M.; Glatz, M.; Gorgas, N.; Stçger, B.; Pittenauer, E.; Allmaier, G.; Veiros, L. F.; Kirchner, K. Chem.-Eur. J. 2016, 22, 12316.

[66] Fertig, R.; Irrgang, T.; Freitag, F.; Zander, J.; Kempe, R. ACS Catal. 2018, 9, 8525 .

[67] Esteruelas, M. A.; Honczek, N.; Valencia, M.; Oñate, E. ; Oliván, M. Organometallics 2011, 30, 2468.

[68] Madsen, R.; Azizi, K. ChemCatChem 2018, 53, 1.

(Zhao, X.) 